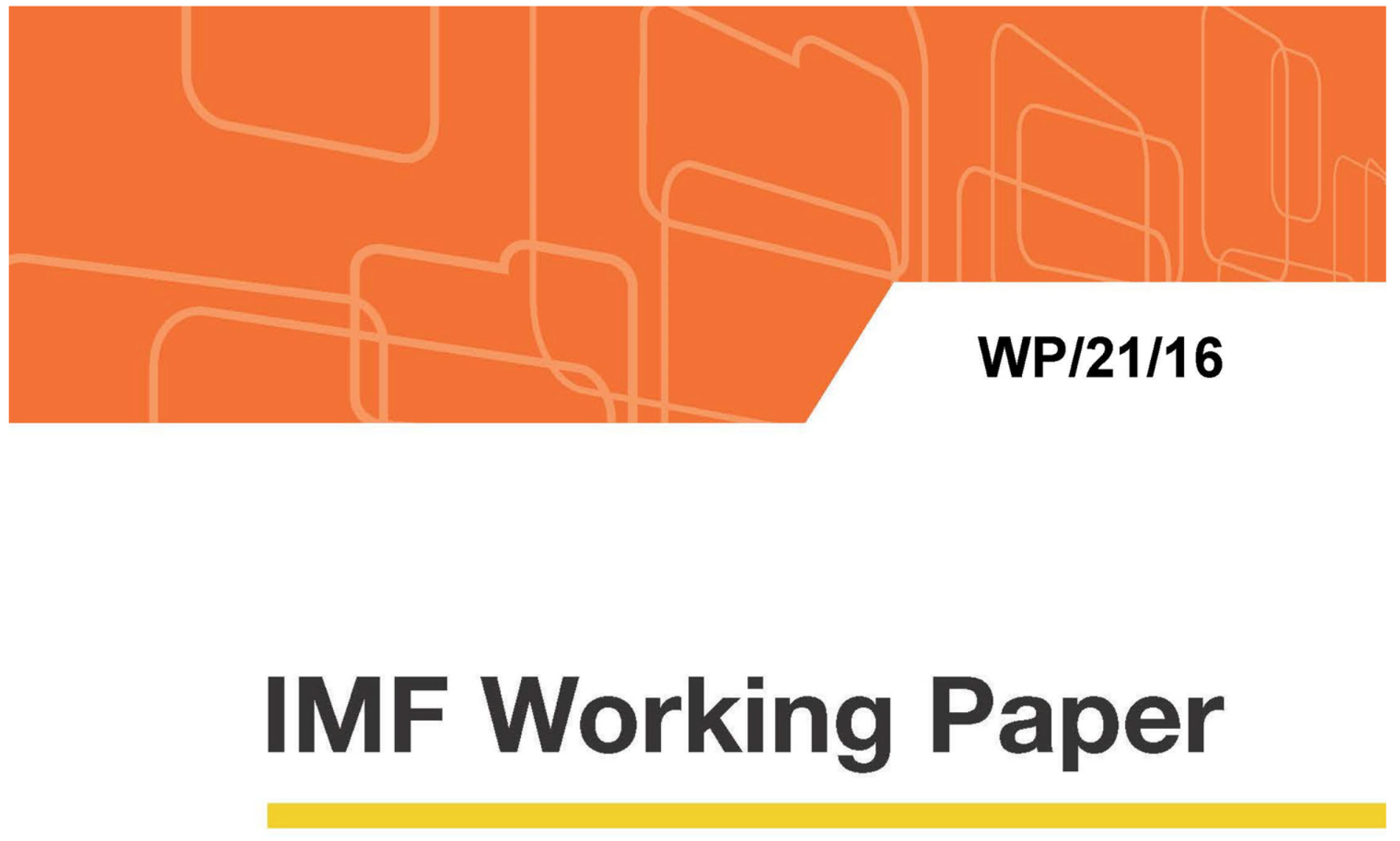

\title{
Flattening the Insolvency Curve: Promoting Corporate Restructuring in Asia and the Pacific in the Post-C19 Recovery
}

by A. Bauer, R. Craig, J. Garrido, K. Kang, K. Kashiwase, S. Kim, Y. Liu, and S. Rafiq

IMF Working Papers describe research in progress by the author(s) and are published to elicit comments and to encourage debate. The views expressed in IMF Working Papers are those of the author(s) and do not necessarily represent the views of the IMF, its Executive Board, or IMF management.

$$
\text { I N T ER N A T I O N A L M O N E TAR Y F U N D }
$$



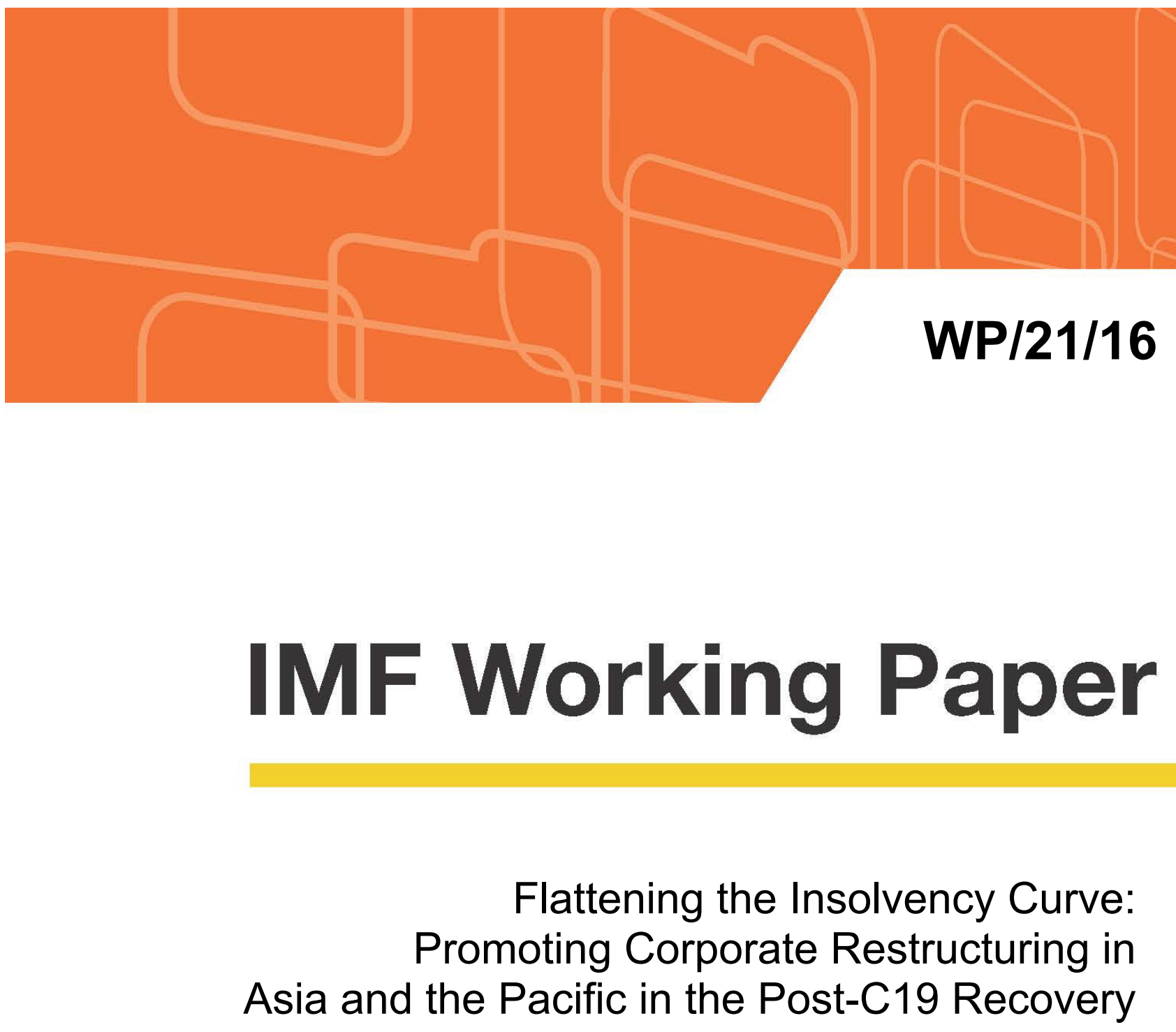

by A. Bauer, R. Craig, J. Garrido, K. Kang, K. Kashiwase, S. Kim, Y. Liu, and S. Rafiq

IMF Working Papers describe research in progress by the author(s) and are published to elicit comments and to encourage debate. The views expressed in IMF Working Papers are those of the author(s) and do not necessarily represent the views of the IMF, its Executive Board, or IMF management.

$$
\text { I N T E R N A T I O N A L M O N E T A R Y F U N D }
$$




\title{
IMF Working Paper
}

Asia and Pacific Department and Legal Department

\section{Flattening the Insolvency Curve: Promoting Corporate Restructuring in Asia and the Pacific in the Post-C19 Recovery}

\author{
Prepared by A. Bauer, R. Craig, J. Garrido, K. Kang, K. Kashiwase, S. Kim, Y. Liu, \\ and S. Rafiq
}

Authorized for distribution by Andreas Bauer and Yan Liu

January 2021

\section{IMF Working Papers describe research in progress by the author(s) and are published to elicit comments and to encourage debate. The views expressed in IMF Working Papers are those of the author(s) and do not necessarily represent the views of the IMF, its Executive Board, or IMF management.}

\begin{abstract}
The Coronavirus disease (COVID-19) triggered a sharp contraction of economic activity across Asia and the Pacific. Policymakers adopted a "whatever it takes" approach in their initial response, relying mainly on liquidity support to help firms survive the shock. This paper discusses how the initial policy response should evolve as the region's economies stabilize and enter the recovery phase. Many firms will need to repair their balance sheets and adjust their business models to the post-pandemic realities. The priority will be to support this process by facilitating the efficient restructuring of viable firms while allowing nonviable firms to exit. This requires action on three complementary fronts: reinforcing private debt resolution frameworks to flatten the insolvency curve, ensuring that adequate financing is available to support corporate restructuring, and facilitating access to equity to speed up the reallocation of jobs and capital into growth sectors.

JEL Classification Numbers: E2, E6, G2, G3, H3, H8

Keywords: Covid-19, fiscal response, financial sector policy, corporate restructuring, insolvency frameworks

Author's E-Mail Address: ABauer@imf.org, RCraig@imf.org, JGarrido@imf.org, KKang@,imf.org, KKashiwase@imf.org, Skim5@imf.org, YLiu@imf.org, SRafiq@,imf.org
\end{abstract}




\section{TABLE OF CONTENTS}

I. Introduction

II. An Unprecedented Policy Response to a Crisis Like no Other

III. Moving from The Initial Liquidity Support to Solvency Support 10

IV. Key Policies For the Corporate Sector in the Recovery Phase 14

A. Reinforcing Private Debt Resolution Frameworks to Flatten the Insolvency Curve $\underline{15}$

B. Ensuring Adequate Financing to Support Corporate Restructuring and the Recovery

C. Pivoting to Equity Support for Non-Financial Firms $\frac{22}{25}$

V. Conclusions $\underline{28}$

Annex I. Policy Responses to the Pandemic Shock in Asia and the Pacific $\underline{30}$

Annex II. The Financial Health of Non-Financial Corporations at the Onset of the COVID19 Crisis $\underline{32}$

Annex III. The Impact of the Pandemic on Small and Medium Enterprises 34

Annex IV. The COVID Shock and Structural Change 36

References 38

\section{Boxes}

1. Key Features of Effective Out-of-Court Restructuring Mechanisms

2. Korea's Bank Recapitalization and Financial Stabilization Funds $\underline{18}$

\section{Figures}

I.1. COVID-19 Cases in Asia and the Pacific, January-August 2020

I.2. Evolution of COVID-19-related Restrictions

I.3. Economic and Financial Impact of COVID-19 Outbreaks in Asia and the Pacific ___ $\underline{8}$

II.1. Credit Conditions in Asia and the Pacific $\underline{10}$

III.1. Impact of the COVID-19 Shock on the Financial Health of Non-Financial Corporations

III.2. Rating Downgrades of Non-Financial Corporations

III.3. Evolution of Insolvency Cases in Past Crises

III.4. Relative Performance of Financial Stocks in Asia and the Pacific 14

III.5. Bank Median Probabilities of Default in Asia and the Pacific 14

IV.1. Flattening the Insolvency Curve 16

IV.2. Decision Tree for the Triage of Enterprises in Distress 17

A.1. Profitability of Non-Financial Companies in Asia and the Pacific $\underline{32}$

A.2. Corporate Debt and Leverage: Nonfinancial Corporate (NFC) Sector $\underline{33}$

A.3. Debt at Risk in Asia and the Pacific

$\underline{33}$


A.4. Importance of Small and Medium Enterprises in Asia and Pacific $\underline{34}$

A.5. Equity Return Dispersion in Asia and the Pacific

A.6. Sectoral Dispersion of Corporate Ratings Downgrades in 2020

\section{Tables}

IV.1. Insolvency Regimes in Asia and the Pacific-Available Tools for Restructuring and Reorganization $\underline{21}$

IV.2. Capital Adequacy and Liquidity in Banking Sector: Selected Economies

23

A.1. Scale of Policy Response in the Initial 


\section{INTRODUCTION ${ }^{1}$}

The outbreak of the coronavirus disease (COVID-19) triggered an economic contraction of unprecedented depth and synchronization. In Asia and the Pacific, most major economies experienced infection peaks between March and April of 2020, although in some countries new cases continued rising through the summer. Most governments implemented stringent lockdowns to limit the spread of the virus. The decline in mobility, along with the collapse in external demand, caused a sharp downturn in regional activity that was broader and deeper than experienced in the Global Financial Crisis (GFC).

Policymakers in Asia and the Pacific adopted a "whatever it takes" approach in their initial response to help firms survive the shock and prevent a more severe economic collapse. Governments and central banks across the region rapidly deployed monetary, fiscal, and financial sector policies on an unprecedented scale, which helped prevent negative feedback loops that could have exacerbated the economic downturn. In the corporate sector, the immediate objective was to help firms survive the severe liquidity squeeze triggered by a collapse in operating income and prevent large-scale job losses.

This paper discusses how the policy support for the corporate sector should evolve as economies in the region stabilize and enter the recovery phase. The pandemic has contributed to a depletion of working capital and an increase in debt for many firms, raising insolvency risks and limiting their ability to restore production. Despite the availability of a vaccine, it is also expected to trigger important structural change, including shifts in consumer preferences and a reconfiguration of supply chains. Firms will thus have to both repair their balance sheets and adjust their business models to operate successfully in the post-pandemic economy. Authorities in the region should facilitate this adjustment while developing more robust policy frameworks and institutions for the future.

The immediate priority for policymakers is to avoid a crippling wave of drawn-out insolvencies and defaults and facilitate efficient restructuring of viable firms while allowing nonviable firms to exit. Policy support for firms will have to pivot from broad-based liquidity support to measures that help restore the solvency of viable firms. This involves addressing excessive corporate leverage while mobilizing funding for new investment and retooling. The depth and broad-based nature of the pandemic shock, the unusually large uncertainty about its duration and sectoral impact, and the large negative macroeconomic and social externalities that mass bankruptcies would generate justify active government support.

In this new phase of pandemic response, the specific measures appropriate for each country will vary depending on the fiscal and monetary support extended when the pandemic hit, the effectiveness and capacity of existing insolvency frameworks, the state of financial development, and the available macroeconomic policy space. The uncertainty about the persistence of the COVID-19 shock means that many of the corporate support measures introduced, such as emergency liquidity support, credit guarantees, and direct fiscal transfers, should continue until there are clear signs of a robust recovery. These measures, however, should

\footnotetext{
${ }^{1}$ The authors would like to thank Romain Duval for helpful comments and suggestions. Paola Castillo provided able research assistance and Livia Tolentino editorial support.
} 
be complemented and gradually replaced by policies geared toward facilitating and supporting corporate restructuring. Among them, the following three areas will be of particular importance:

- Reinforcing private debt resolution frameworks to "flatten the insolvency curve" and facilitate large scale corporate restructuring. The flow of insolvency cases has been contained so far by the initial liquidity support and other interim measures, but this is not sustainable over a prolonged period. Greater reliance on out-of-court and hybrid restructuring mechanisms would help address firms' need for financial restructuring while effectively "flattening the insolvency curve" by reducing the number of court cases to a manageable level. At the same time, the formal in-court debt resolution frameworks should be strengthened to ensure a more efficient formal insolvency process for firms with major viability problems. Simplified procedures for SMEs can further help resolve a high number of small insolvency cases at a reduced cost.

- Ensuring adequate financing to support corporate restructuring in the post-pandemic recovery. Banks provide the bulk of corporate credit in most financial systems in Asia and the Pacific. Authorities should use the flexibility built into the existing regulatory and supervisory frameworks to ensure that banks maintain an adequate flow of credit to the economy. In some cases, easing macroprudential settings will be appropriate. Maintaining capital well above prudential minimum levels will support banks in providing new financing and taking on more risk in corporate restructurings. For this, policymakers may need to temporarily curb capital distributions and strengthen incentives for banks to proactively raise private capital. A publicly funded vehicle for equity injections can be a useful backstop for banks if private capital is not forthcoming. Non-bank sources of financing for corporate restructuring, including special investment vehicles, should also be promoted.

- Facilitating access to risk capital for existing firms and startups to speed up the reallocation of resources into growth sectors. Many firms in Asia and the Pacific are already highly leveraged and will need new equity to retool in a post-pandemic world. Policymakers can help by eliminating the tax bias against equity, providing incentives for debt-to-equity conversions, simplifying regulations and reducing the cost of launching startups. Small and medium-sized firms (SMEs) are a significant source of employment in the region and have been hit hard by the crisis, which may justify additional support. Authorities can promote new financial instruments for SMEs such as equity-like finance that does not involve shareholder control and, hence, may be more attractive to firm owners (e.g., non-voting preferred shares, convertible subordinated bonds, or profit participation loans). In situations where private equity may be insufficient owing to heightened uncertainty after the pandemic, the public sector can facilitate raising new equality, as a "venture capitalist of last resort" with appropriate safeguards to guard against moral hazard. This can catalyze private risk-taking and lay the foundations for a more robust equity culture in Asia.

This paper is organized as follows: Section II provides a short summary of the impact of the COVID-19 outbreak on economies in Asia and the Pacific and how policymakers responded to help firms. Section III discusses why and how the initial policy response will need to adjust in the next phase as economies recover and financial support is scaled back. Section IV lays out the key policies to support resource reallocation in the corporate sectors in the recovery phase. Section V offers brief concluding reflections. 


\section{An UnPrecedented Policy Response to A Crisis Like no Other}

The outbreak of COVID-19 triggered an economic contraction of unprecedented depth and synchronization. Economic activity and trade fell sharply in the first half of 2020 as countries across the globe introduced measures to contain the pandemic. Suspensions of air travel, border closures, and social distancing had a severe negative impact on business activity, with sectors such as hospitality and tourism, manufacturing, and personal services particularly hard hit.

\section{In Asia and the Pacific, the timing and intensity of the pandemic outbreaks varied across} countries. ${ }^{2}$ China detected its first cases in late-2019 and experienced a peak in new cases in February 2020. In most major economies, a first wave of infections peaked between March and April, although in some countries the number of new cases continued to rise steadily into the summer (Chart I.1). More recently, several countries that contained the first wave of infections have experienced renewed local outbreaks of varying intensity. By contrast, most Pacific island countries have so far been able to avoid local outbreaks of the virus.

Chart I.1. COVID-19 Cases in Asia and the Pacific, January-August 2020
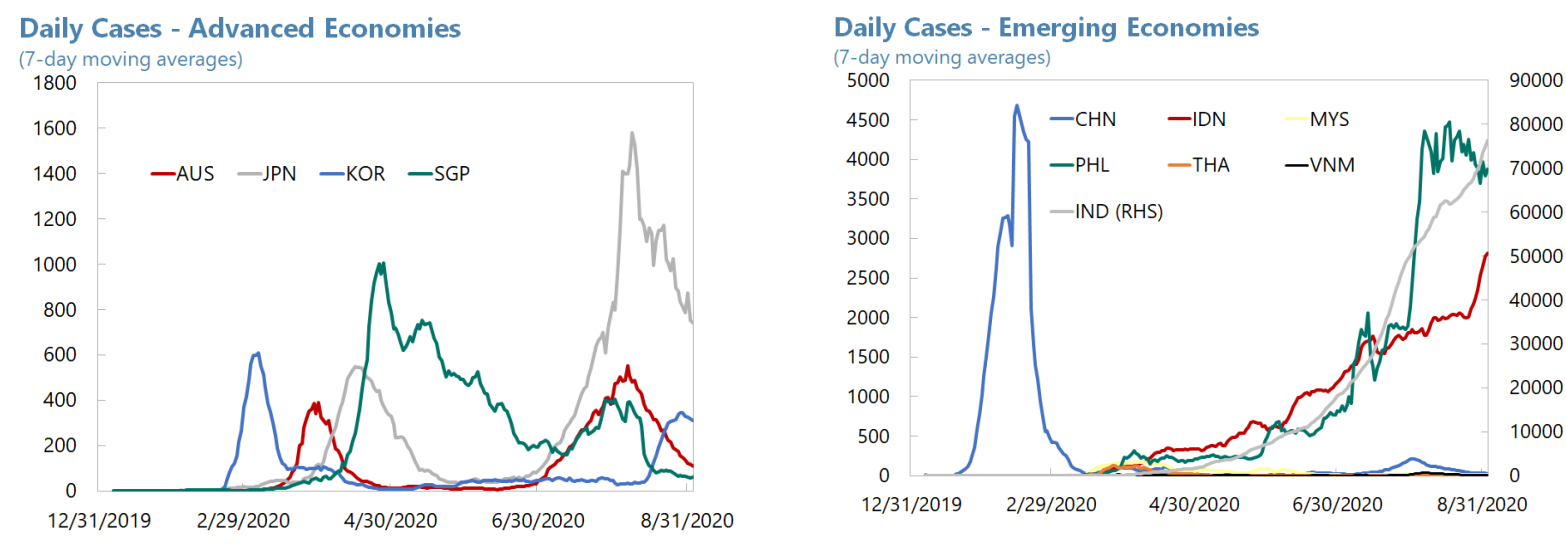

Sources: Johns Hopkins University Center of Systems Science and Engineering and IMF staff calculations

Most governments in the region implemented stringent lockdown policies that helped contain the spread of the virus. The intensity of containment measures peaked in March and April in most countries, and restrictions on movement and business operations were gradually relaxed from May onward as infections fell (Chart I.2). However, in countries with renewed local outbreaks, restrictions were tightened again temporarily during the summer.

\footnotetext{
${ }^{2}$ This paper focuses primarily on a group of larger economies in Asia and the Pacific, comprising Australia, China, Hong Kong, SAR, India, Indonesia, Japan, Korea, Malaysia, the Philippines, Singapore, Thailand and Vietnam.
} 
Chart I.2. Evolution of COVID-19-Related Restrictions

Stringency Index, Jan-Aug, 2020 1/

(Daily average)

\begin{tabular}{|c|c|c|c|c|c|c|c|c|c|c|c|}
\hline & Jan & Feb & Mar & Apr & May & Jun & Jul & Aug 1/ & & eak & Trough 2/ \\
\hline Australia (AUS) & 2.0 & 14.5 & 51.2 & 92.0 & 83.4 & 75.9 & 76.5 & 79.2 & 92.1 & end-Mar & 73.6 mid-Jun \\
\hline Hong Kong, SAR (HKG) & - & - & 31.9 & 60.5 & 57.4 & 40.7 & 39.3 & 38.9 & 68.5 & beg-Apr & 38.9 end-May \\
\hline Japan (JPN) & 2.2 & 21.8 & 41.2 & 45.7 & 41.9 & 25.9 & 26.1 & 30.6 & 47.2 & mid-Apr & 24.1 mid-Jun \\
\hline Korea (KOR) & - & - & 41.4 & 89.3 & 85.2 & 79.2 & 75.8 & 75.9 & 89.3 & end-Mar & $74.1 \mathrm{mid}-\mathrm{Jul}$ \\
\hline Singapore (SGP) & 1.1 & 4.7 & 45.2 & 90.9 & 93.3 & 91.8 & 81.8 & 73.2 & 93.5 & beg-May & 73.2 beg-Aug \\
\hline China (CHN) & 0.1 & 36.2 & 62.6 & 66.6 & 43.7 & 56.9 & 50.7 & 50.5 & 82.4 & mid-Apr & 39.8 mid-May \\
\hline India (IND) & - & 4.6 & 58.2 & 84.7 & 78.9 & 74.1 & 59.6 & 24.1 & 85.2 & mid-Mar & 24.1 mid-Aug \\
\hline Indonesia (IDN) & n.a. & n.a. & 19.4 & 96.3 & 71.2 & 36.1 & 15.6 & 26.9 & 96.3 & end-Mar & 11.1 end-Jul \\
\hline Malaysia (MYS) & 0.5 & 5.6 & 34.9 & 85.3 & 86.9 & 80.1 & 71.2 & 67.6 & 88.0 & mid-Apr & 67.6 mid-Jul \\
\hline Philippines (PHL) & - & 3.8 & 40.3 & 94.8 & 99.5 & 96.1 & 91.0 & 88.0 & 100.0 & mid-Apr & 77.8 mid-Mar \\
\hline Thailand (THA) & 1.6 & 8.7 & 62.2 & 90.0 & 96.3 & 84.9 & 79.8 & 68.5 & 100.0 & mid-May & 68.5 beg-Aug \\
\hline Vietnam (VNM) & 1.3 & 8.9 & 54.6 & 91.4 & 79.9 & 60.8 & 52.3 & 50.0 & 100.0 & end-Mar & 50.0 mid-Jul \\
\hline
\end{tabular}

$1 /$ The colors of the heatmap range from the highest (dark red) to the lowest (dark green) values of the average monthly stringency index during the period January through August 2020. The data for August shows the value as of August 21.

2/ A trough is identified as the lowest index value after the first wave peak in March-May.

Sources: Oxford COVID-19 Government Response Tracker; and IMF staff calculations.

\section{The containment measures to fight the pandemic weighed heavily on the region's}

economies. Most countries experienced downturns that were more broad-based and deeper than in the GFC. Financial conditions tightened sharply in March amid heightened uncertainty, with U.S. dollar and domestic currency funding sources seizing up and benchmark stock market indices plummeting. Consumer and business sentiment fell across the region and activity in both services and manufacturing declined steeply. Growth forecasts were downgraded substantially, with real GDP expected to contract in 2020 and only partially recover in 2021 (Chart I.3).

Chart I.3. Economic and Financial Impact of COVID-19 Outbreaks in Asia and the Pacific 1/
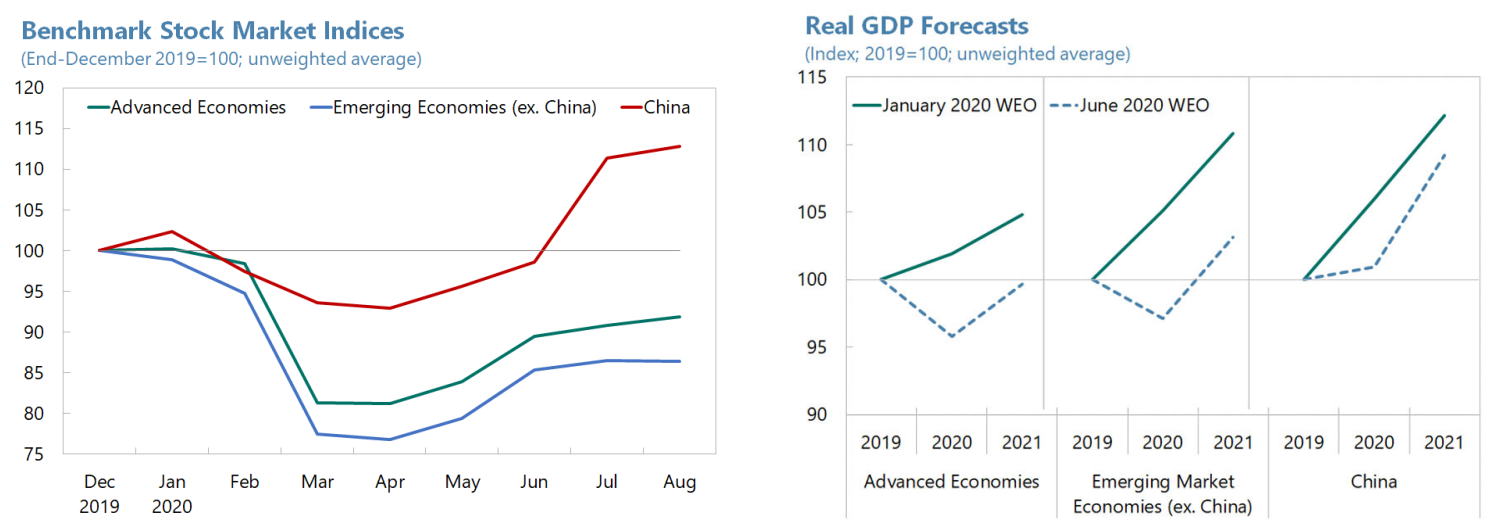

1/ Advanced economies include Australia, Hong Kong SAR, Japan, Korea, and Singapore. Emerging economies include India and ASEAN-5 (Indonesia, Malaysia, Philippines, Thailand, and Vietnam).

Sources: CEIC Data; Haver Analytics; IMF World Economic Outlook (January and June, 2020); and IMF staff calculations.

Against this severe backdrop, policymakers in Asia and the Pacific adopted a "whatever it takes" approach in their initial response. The immediate objectives were to help firms survive the liquidity squeeze from the collapse in operating income and protect employment. This led 
governments and central banks to deploy a combination of monetary, fiscal and financial policies on an unprecedented scale (Annex I):

- Fiscal support was provided through "on-budget" measures, such as subsidies to firms to maintain employment and deferral of tax obligations, as well as a range of quasi-fiscal "offbudget" measures, such as loan guarantees.

- Monetary policy relied on both traditional policy rate cuts and a variety of unconventional instruments to ease financing conditions. Quantitative instruments were used to target liquidity support to stressed corporate funding markets and firms facing severe cash flow shortfalls.

- Financial sector policies supported firms through stepped up lending by state-owned commercial or development banks; time-bound moratoria on debt service payments and restrictions on the use of insolvency and debt enforcement procedures; temporary easing of macroprudential settings for liquidity and capital buffers, and regulatory guidance that included, in a few cases, forbearance on bank loan classification.

Policy support measures were often combined for greater impact. For example, many central banks provided funding to banks for on-lending to corporates, particularly SMEs, while governments provided guarantees. This was intended to avoid a liquidity squeeze and support payments during a highly uncertain period. Some countries, such as Korea, created special purpose vehicles (SPVs) to purchase corporate securities and loans to SMEs, with funding from the central bank and the government providing equity for loss absorption.

The choice of policy instruments reflected the extent of financial system development across the region. In bank-dominated financial systems with a larger share of SMEs, policy focused on ensuring the continued flow of bank credit to firms. In more sophisticated systems where financial markets play a greater role in corporate finance, policy focused more on stabilizing funding markets using a variety of instruments to support market liquidity.

The rapid implementation and scale of the initial policy response helped prevent negative feedback loops that could have exacerbated the economic downturn.

- Decisive monetary easing in Asia and the Pacific and in major advanced economies helped stabilize financial markets and ease financial conditions. Equity markets rebounded and, overall, declines were shallower than in the GFC. Pressures in domestic and dollar funding markets also eased, helped by swap lines provided by the United States Federal Reserve to several countries.

- The policy responses also appear to have been broadly successful in preventing a sharp contraction in bank lending. Credit to the corporate sector rose in the first half of 2020 in most of the region's major economies (Chart II.1). Bank lending standards eased in several countries in the first quarter on the back of policy support but tightened somewhat subsequently. Signs of deteriorating loan quality have been muted by the large policy support provided as well as moratoria on loan repayments. Nevertheless, in a few countries an uptick in special mention and non-performing loans has been observed recently. 
Chart II.1. Credit Conditions in Asia and the Pacific 1/
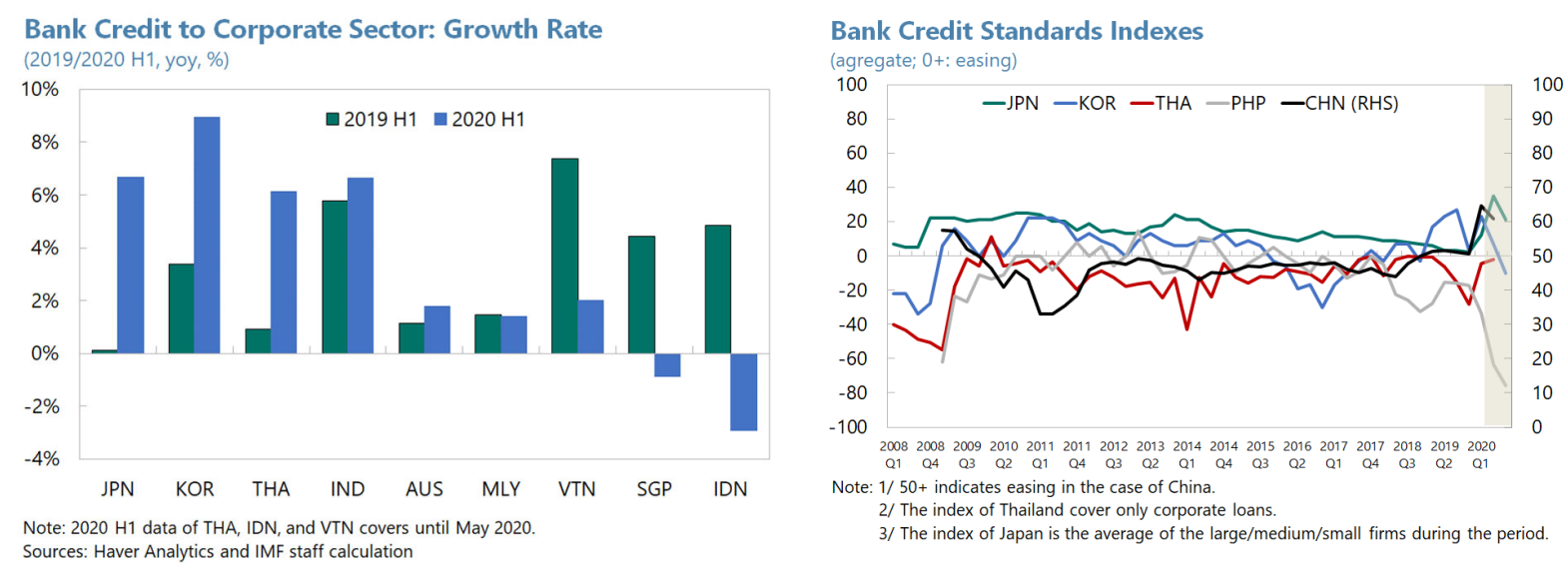

\section{Moving From The InITIAL LIQUIDITY SUPPORT To SOLVENCY SUPPORT}

The initial policy response was critical to help firms survive the sudden shock and prevent a more severe economic collapse, but it will need to be reconfigured to enable a robust recovery. Many firms have been financially weakened by the pandemic. They are now facing higher insolvency risks, which could limit their ability to restore production and grow. In some cases, firms have been able to remain open but their business models may no longer be viable in the post-pandemic economy. Hence, while the number of insolvency cases has remained relatively muted so far in most countries, these could rise materially once broad-based liquidity support is being phased out. ${ }^{3}$ Against this backdrop, the focus of policy support should shift to helping firms restructure their operations and restore solvency.

\section{The increased financial fragility of Asian and Pacific firms is evident in a range of} corporate vulnerability indicators. Corporate debt at risk was already elevated on the eve of the pandemic, reflecting the rise in leverage since the GFC (Annex II). In 2019, about 36 percent of the region's total debt was held by firms with an interest coverage ratio (ICR) below two, with shares ranging from 10 percent in Japan to as high as 50 percent in Indonesia. Available data for the first half of 2020 suggests that many non-financial companies experienced significant declines in revenues and earnings, while the unprecedented liquidity support provided in response to the shock increased corporate debt burdens. This has pushed up the share of corporate debt at risk to 54 percent, led to further increases in corporate leverage, and triggered negative corporate rating actions (Charts III.1 and III.2), all indicative of rising financial fragility among corporates in the region. As liquidity support, moratoriums and other regulatory forbearance measures are scaled back in the recovery phase, many firms with shortfalls in working capital and significant debt overhangs will come under pressure. This increases the risk of a wave of insolvencies that could hamstring the recovery.

\footnotetext{
${ }^{3}$ For instance, Altman (2020) foresees a second wave of business bankruptcies in the United States, likely to hit in the second half of 2021. Estimates by Banerjee et. al. (2020) for a broader sample of advanced economies also suggest a possible rise in bankruptcies by late 2021 .
} 
Chart III.1. Impact of the COVID-19 Shock on the Financial Health of Non-Financial Corporations
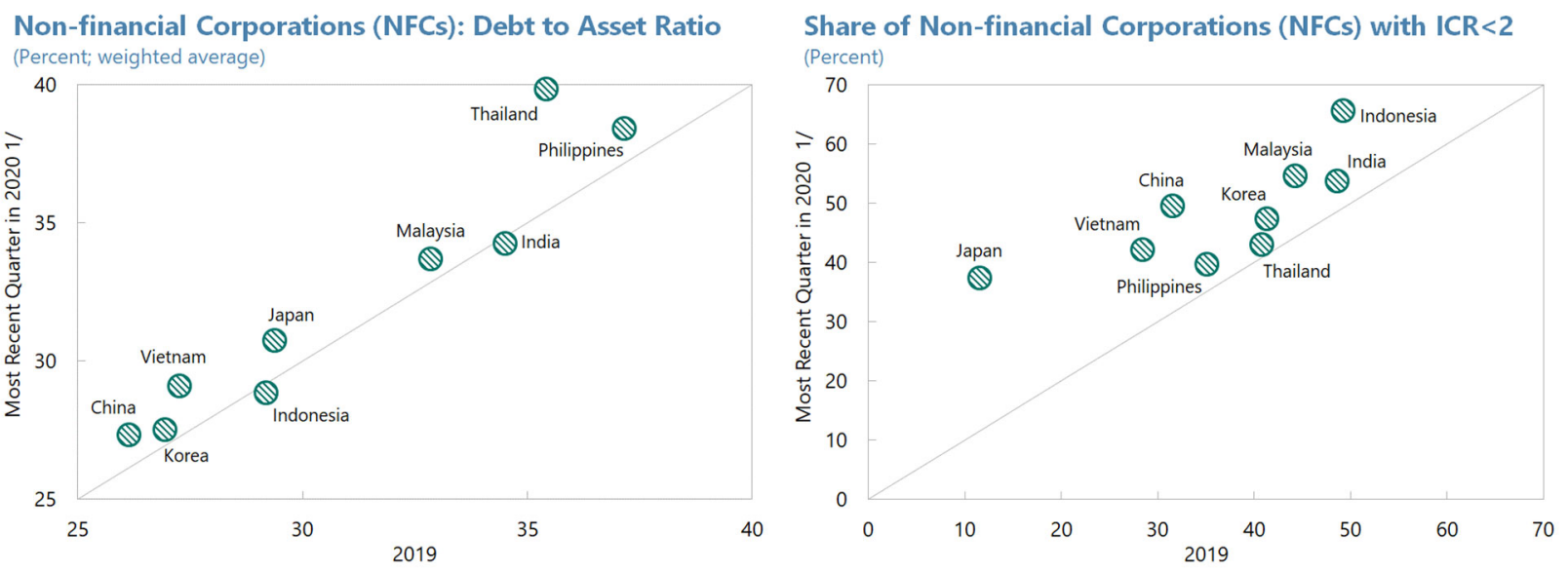

1/ The charts show the most recent data, including 2020Q1 for Korea, China, India, Malaysia, Philippines, Thailand, and 2020Q2 for Japan, Indonesia, and Vietnam. India is based on fiscal year, which runs from April through March. Calendar year is used for other countries. Firms with market capitalization of at least US\$1 million are included.

Sources: S\&P Global Market Intelligence; and IMF staff calculations.

Chart III.2. Rating Downgrades of Non-Financial Corporations 1/


1/ Data for rating downgrades for 2020 is through end-July.

2/ Regions include Latin America and the Caribbean (LAC), Middle East and North Africa, the Caucasus and Central Asia (MENA \& CCA), and Sub-Saharan Africa (SSA).

Sources: S\&P Global Market Intelligence; and IMF staff calculations.

SMEs are experiencing greater financial stress than larger firms. SMEs are particularly concentrated in services, which have suffered more under the pandemic. Compared to large firms, SMEs have more limited access to financing due to their lack of collateral, small size, and inability to tap the capital markets, making them less resilient to shocks. While timely balance sheet data for SMEs is scarce, recent surveys suggest that many SMEs are facing serious cash flow problems and closures have spiked (Annex III). Model-based simulations (IMF 2020b) using firm-level data for 21 countries, including Japan and Korea, show that firms in financial distress and at risk of insolvency account for 9 to 13 percent of total SME (in sample) employment, depending on the stress measure chosen-insolvency or illiquidity. This represents 
almost a doubling of SME jobs at risk due to liquidity risks (and a 50 percent increase due to insolvency risks) vis-à-vis a scenario without COVID-19.

Structural changes triggered by the pandemic pose additional challenges. The behavioral responses to the virus are accelerating ongoing transitions such as the switch from brick-andmortar retail to online commerce or the expansion of digital payments and finance. In addition, the pandemic may lead to permanent changes in consumer preferences and reconfigurations of supply chains. These changes will disproportionately impact some sectors, such as hospitality, transportation and logistics, and retail trade, while creating opportunities for rapid growth in others. The concentration of negative corporate credit rating actions in these sectors is a sign that investors expect a significant reallocation of resources (Annex IV). Similarly, the rise in the dispersion of stock prices in the United States and many of Asia and Pacific markets during the pandemic may also be an indication of this expected shift (Barrero et al., 2020).

Once economies have stabilized, the policy response will have to adjust to facilitate a reallocation of resources. A robust recovery will depend on the ability of firms to reconfigure their businesses and invest in expanding sectors. Nonviable firms should be allowed to exit to avoid creating "zombies" that lock up resources used more productively elsewhere and deter entry. The initial fiscal and financial measures that focused on maintaining corporate sector operations and employment will need to be phased out to avoid holding back this transformation. With respect to employment, policy should shift gradually from protecting specific jobs to the provision of direct support for workers through active labor market policies that facilitate job switching. On the financial side, support should shift gradually from the provision of emergency liquidity to other modes of financing that strengthen solvency and promote restructuring.

The key challenge for policymakers is to facilitate this transition without generating a disruptive wave of insolvencies. This will require a process of "corporate triage" —identifying firms that can be viable in the post-pandemic environment and supporting their restructuring while providing avenues for non-viable firms to wind down expeditiously.

\section{The ability of countries to manage this transition effectively will depend on the institutional capacity of their insolvency systems and the quality of their legal frameworks.}

- Many of the larger economies, including Japan, Korea, Australia, and most recently, China and India, have well-established insolvency frameworks, capable of handling a significant number of cases. However, there are also countries - especially those with lower incomes such as Cambodia, Lao PDR, Myanmar, or Mongolia - with minimal insolvency practices. ${ }^{4}$ The low number of formal insolvencies in these cases reflects the limited professional and judicial capacity, social stigma, low trust, and lack of familiarity with the insolvency system. As a result, few insolvency cases are handled by the courts, and businesses that could be viable with restructuring simply close their doors.

\footnotetext{
${ }^{4}$ For instance, Lao PDR is classified as a "no practice" country in the "Resolving Insolvency" indicator of the World Bank's Doing Business report, implying that there have been less than 5 insolvency cases in each of the last 5 years. Mongolia enacted its first insolvency law in 1997, but not a single reorganization case has been successfully completed since then. Myanmar promulgated a new Insolvency Law earlier this year after repealing a largely inoperative Act dating from 1920.
} 
- An evaluation of the key features of legal frameworks - informal and preventive restructuring, reorganization, liquidation, and debt enforcement regimes across the regionindicates that insolvency systems are very advanced in some countries (e.g., Japan, Korea), while in other countries there remains considerable room for improvement. ${ }^{5}$ Some countries in the region have good court-led restructuring mechanisms but lack adequate informal, outof-court restructuring tools. In addition, some countries have legal and judicial systems that work well for large firms but can be excessively complex and costly for SMEs, leaving them without access to a workable debt restructuring mechanism.

The scale of the COVID-19 shock could pose challenges even for countries with more robust insolvency practices and frameworks. Experience suggests that insolvency caseloads can rise far above "normal" levels during major crises (Chart III.3). And, if large enough, such surges can overwhelm the capacity of court systems. When this happens, viable but insolvent firms become tied up in prolonged reorganizations that erode franchise value, leading to unnecessary liquidations (Iverson, 2018). In countries with minimal or limited insolvency practice, the insolvency system is unable to perform its role of returning viable but insolvent firms to health. When this is the case, failure to make payment to financial creditors, trade creditors, or public authorities, can result in enforcement actions that cascade and lead to closures of viable firms rather than restructuring or reorganization. These weaknesses in the insolvency system could exacerbate the negative economic and social impact of the pandemic, slow the pace of recovery, and leave long-lasting scars in the form of permanently lower output.

Chart III.3. Examples of Insolvency Curves in Past Crises
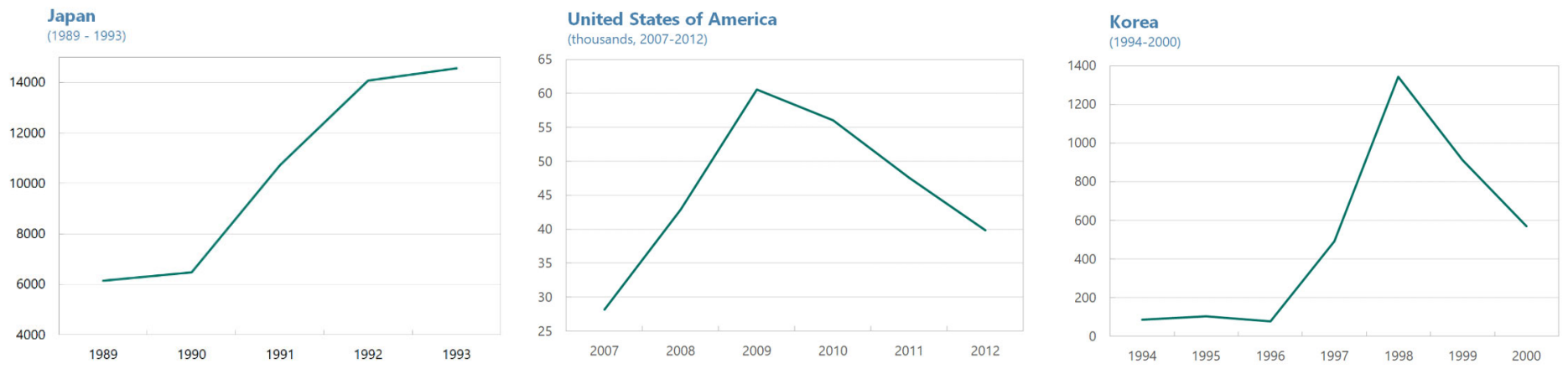

Sources: KERI, Euler/Hermes, Trading Economics.

Corporate restructuring will also require the mobilization of fresh funding. Given their dominant role in the region, banks have an essential role to play in this process. Banks have so far been relatively insulated from the pandemic as the initial policy response essentially froze the status quo through massive liquidity support, credit guarantees, payment moratoria and, in some cases, forbearance. However, as this support is scaled back the solvency of firms will become clearer, pressuring banks to restructure and/or write down some of their loans. Bank stocks have underperformed the broader equity markets since the onset of the crisis (Chart III.4) and default

\footnotetext{
${ }^{5}$ The assessment of the quality of insolvency legal frameworks is generally less informative in countries where insolvency practice is minimal. In such countries, the legislation by itself may not provide a good picture of the effectiveness of the insolvency system because many legal provisions have not been tested in practice.
} 
probabilities rose sharply when the pandemic hit, suggesting that markets were concerned about the possibility of large losses on their loan portfolios (Chart III.5). While much of the increase in default probabilities has reversed subsequently, significant loan write-downs remain a risk, especially in emerging and low-income economies of the region, and could limit the ability and willingness of banks to finance firms.

\section{Chart III.4 Relative Performance of Financial Stocks in Asia and the Pacific}

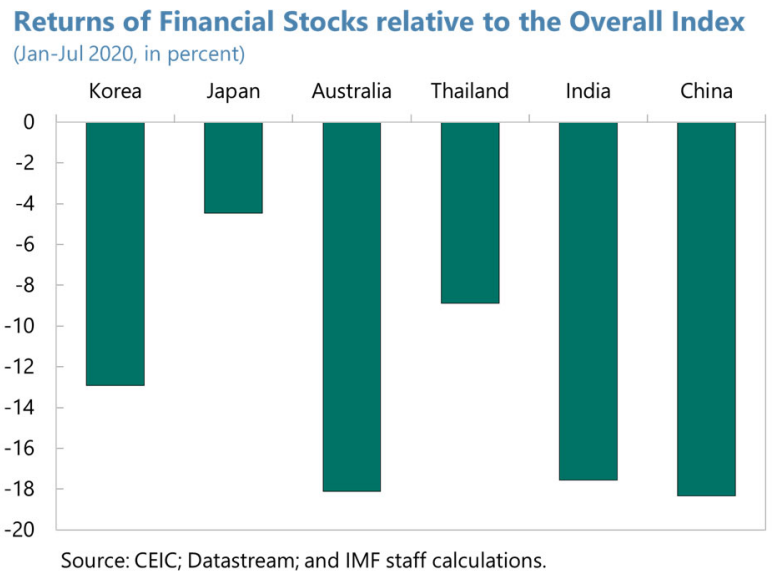

Chart III.5. Bank Median Probabilities of Default in Asia and the Pacific

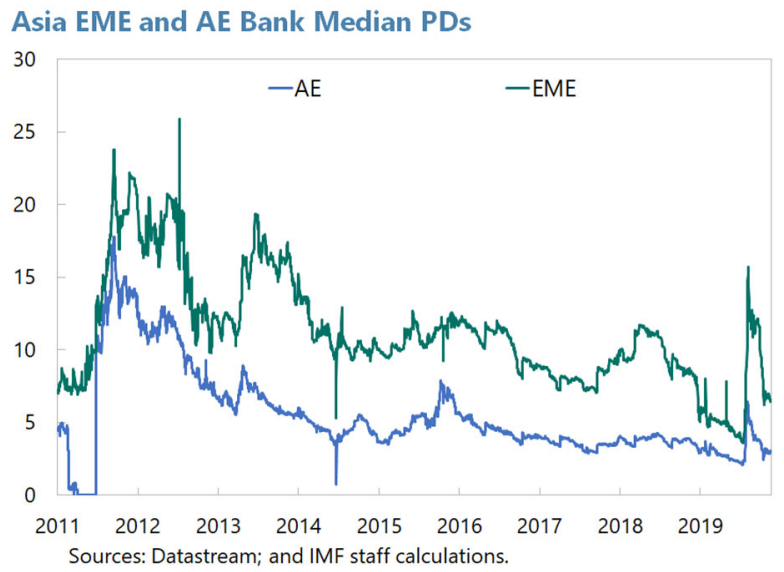

\section{Key Policies For the Corporate Sector in the Recovery Phase}

What are the key policies to help firms in Asia and the Pacific recover from the pandemic and adjust their business models as economies stabilize and recover? This will vary depending on the fiscal and monetary support extended to companies, the effectiveness and capacity of the existing insolvency frameworks, the state of financial development, and the available macroeconomic policy space. In most countries, support measures put in place in the immediate aftermath of the COVID-19 shock, such as emergency liquidity support, credit guarantees, and direct fiscal transfers, should continue until there are clear signs of a robust recovery. However, these policies should be complemented and eventually replaced by measures that facilitate and support corporate restructuring and recapitalization.

The nature of the COVID-19 shock supports more active involvement of the public sector in restoring corporate solvency than in a typical recession. The economic contraction caused by the pandemic has been unusually deep and broad-based, with considerable uncertainty about its duration and sectoral impact. In this environment, private capital may not be forthcoming in terms of speed and quantity, and the textbook response of providing liquidity support against high quality collateral may be insufficient to keep viable firms alive. Policy should thus step in with solvency support to prevent the negative macroeconomic and social externalities that mass bankruptcies would generate (IMF, 2020b). While SMEs are not individually systemic, the aggregate social and economic cost of widespread SME failures would be very high in terms of employment, market concentration, and the fixed investment of restarting similar businesses. Where this is the case, public solvency support may be warranted not just for large or strategic firms but also for SMEs. 
In this phase, policymakers should (re)focus on three complementary policy areas:

- Reinforcing private debt resolution frameworks to flatten the insolvency curve and facilitate large scale restructuring of firms;

- Ensuring that financing is available to support restructuring of firms in the post-pandemic recovery; and

- Facilitating access to equity for existing firms and startups to speed up the reallocation of resources into growth sectors.

\section{A. Reinforcing Private Debt Resolution Frameworks to Flatten the Insolvency Curve}

The initial policy response to the COVID-19 shock included interim measures to reduce the filing of new insolvency cases in most countries in the region. The pandemic has temporarily reduced the activity of courts and the number of new insolvency cases. In addition, some countries (e.g., Singapore, Australia, India) suspended wrongful trading liability of directors to avoid premature insolvencies. ${ }^{6} \mathrm{~A}$ few countries have also implemented moratoria on debt enforcement activities, including for insolvency cases. For instance, in India the moratorium on insolvency cases has been absolute, with the courts not even taking voluntary cases, i.e., cases initiated by debtors. While serving as a stop-gap response to an unprecedented shock, these measures are not sustainable as they interfere with the rights of creditors to recover their loans and delay necessary corporate restructuring and resource reallocation.

Authorities should prepare now to scale back these measures in the recovery phase so that the solvency problems of enterprises can be addressed expeditiously. Actions will depend on the severity of the economic downturn and the potential number of insolvencies, and on each country's institutional capacity to deal with a surge of insolvency cases. Information from applications for financial support by firms can help gauge the likely extent of corporate sector distress once liquidity support is scaled back and other interim measures are removed. In parallel, policymakers should identify remaining weaknesses of their insolvency regimes, and address them in anticipation of a significant increase in insolvency cases. This includes allocating resources to expand the capacity of the court system and other relevant institutions, bearing in mind that substantial increases in court capacity are achievable only in the medium term.

The policy objective should be to "flatten" the insolvency curve so that courts are not overwhelmed once interim measures are lifted. The fundamental function of insolvency systems is to rescue viable enterprises and reallocate the resources of non-viable enterprises to more productive uses. A sudden wave of insolvency cases can prevent the courts from fulfilling this function. Where insolvency cases are likely to surge, a "transition phase" may be needed involving a series of special mechanisms, such as out-of-court or hybrid restructuring procedures, that allow for corporate debt restructuring without or with much-reduced court involvement (Liu, Garrido and DeLong, 2020). This approach effectively "flattens" the

\footnotetext{
${ }^{6}$ Directors of a company may be personally liable for the company's debts if they continue trading when there is no reasonable expectation that the company can avoid insolvency proceedings.
} 
insolvency curve by reducing the number of cases adjudicated by the courts to a level that is commensurate with their administrative capacity, while ensuring that corporate financial distress is addressed expeditiously (Chart IV.1).

\section{Chart IV.1 Flattening the Insolvency Curve}

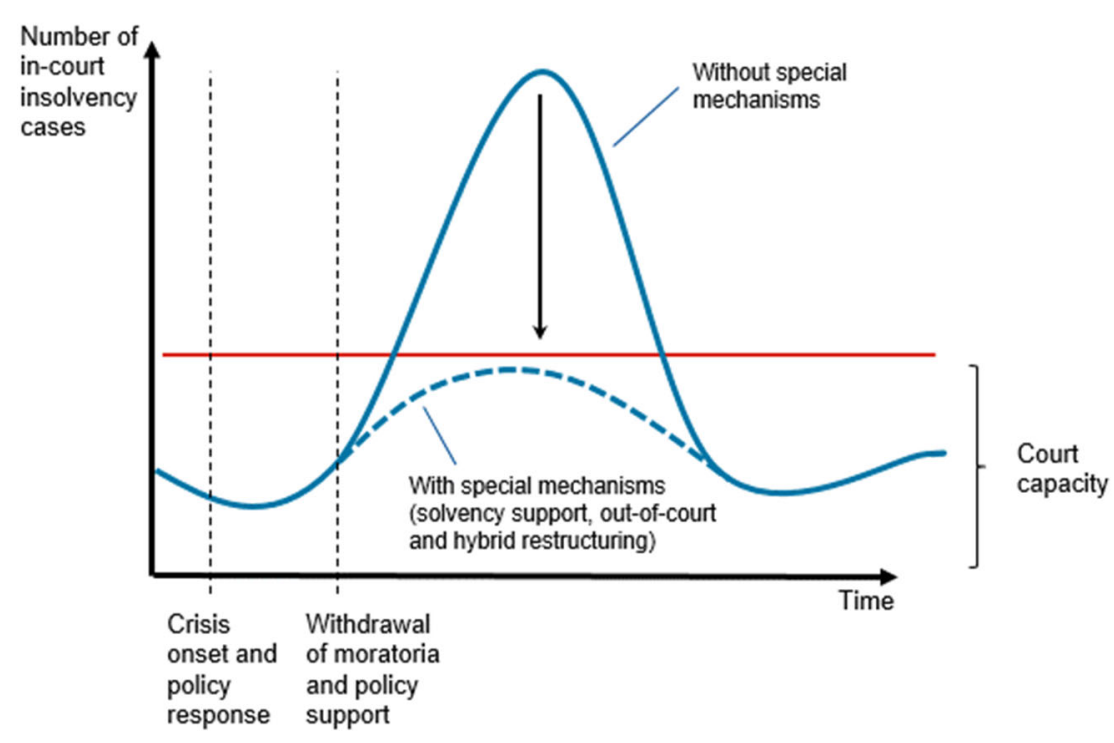

The process of flattening the insolvency curve should start with a "triage" of insolvency cases. The triage process would seek to identify viable firms experiencing relatively straightforward financing problems and address them through informal out-of-court debt restructuring or hybrid restructuring that requires little court involvement. This would leave the court system to focus mainly on firms with major viability problems, which require a formal bankruptcy proceeding to achieve financial restructuring and operational reorganization (Figure IV.2). Separately, in some cases, authorities may identify insolvent firms that merit preservation because of their social or strategic role. These firms, which may be state-owned or private, should be dealt with separately through the provision of fiscal solvency support. 


\section{Chart IV.2 Decision Tree for the Triage of Enterprises in Distress}

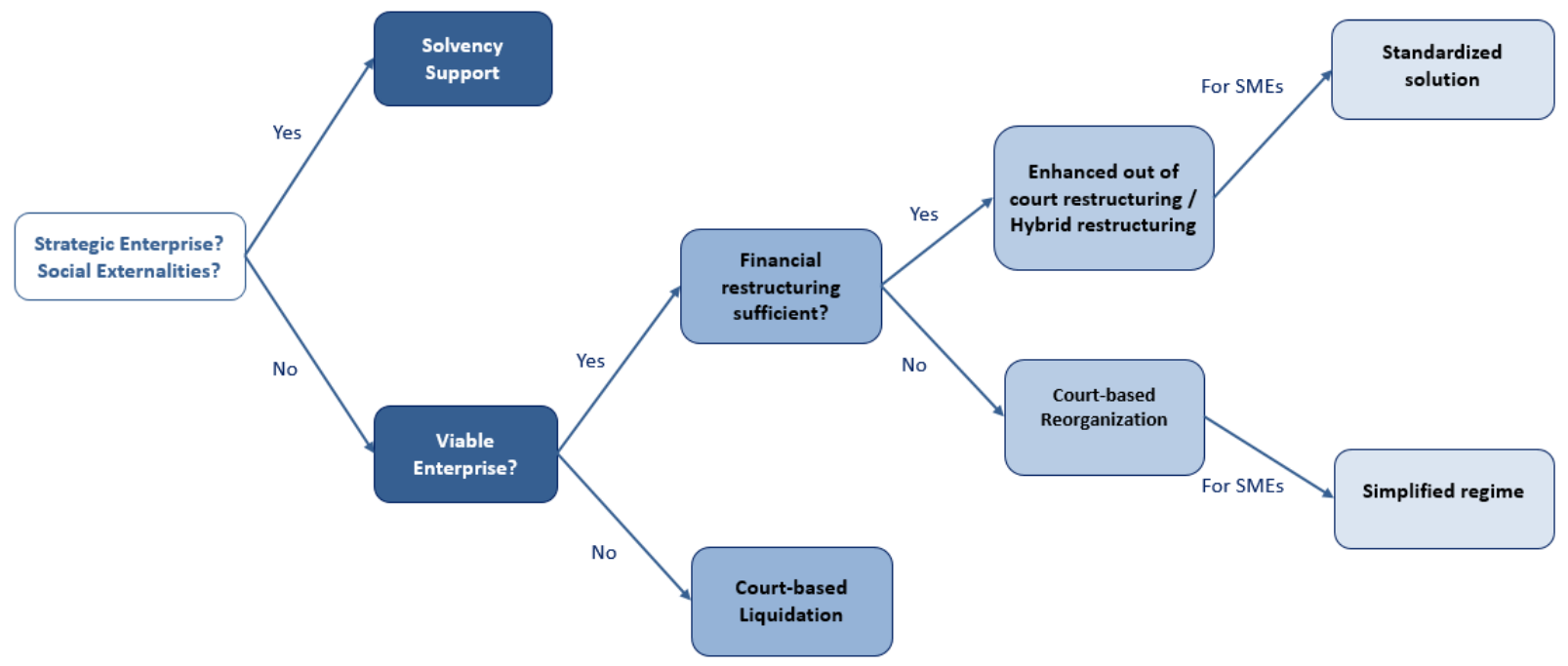

Performing a triage in the current environment will be challenging as the pandemic is altering business models in many sectors. The triage can start with an analysis of firms' financial condition immediately before the pandemic, where a record of sustained profits would be a sign of potential viability. As the pandemic evolves, additional indicators of viability can be developed, including those differentiated by economic sectors and the age of firms. Performance under health restrictions, and projections that take the expected duration of such restrictions into account, can also be integrated into the viability analysis.

Relatively straightforward financial restructuring cases for viable firms should be resolved using special out-of-court mechanisms. Country experience shows that enhanced out-of-court restructuring mechanisms can provide a cost-effective, market-friendly and speedy alternative to formal insolvency proceedings, which can play an important role in a crisis when caseloads rise sharply. In the 1997/98 Asian financial crisis (AFC), the capacity of the insolvency systems in many of the affected countries was minimal. Insolvency laws were often weak and court systems unprepared to resolve complex cases. Because improvements of the legal framework and court capacity take time, several countries (Indonesia, Korea, Malaysia, and Thailand) established special out-of-court debt restructuring mechanisms to tackle corporate distress. This is generally the most effective solution to overcome a gap between court capacity to handle cases and the number of firms that need financial restructuring (Garrido, 2012). Out-of-court mechanisms also fit well into the legal culture in Asia and the Pacific, which tends to prefer negotiated solutions over litigation (Tomasic and Little, 1998).

Out-of-court restructuring mechanisms require a number of features to be effective. They should be market driven but can also benefit from some government involvement, including possibly the provision of financial, regulatory, or tax incentives. General protocols of debt restructuring principles or master restructuring agreements can be employed to foster creditor participation, while restructuring experts can provide support in the out-of-court process and disputes can be resolved through mediation or arbitration. Stand-by agreements can ensure that participating creditors and the debtor abstain from taking actions that alter the relative positions 
of creditors in the restructuring process. Finally, the option to initiate a fast-track insolvency case ("pre-pack") to obtain a prompt and binding judicial confirmation of a proposed restructuring plan can help deal with situations where holdout creditors hinder agreement (Box 1).

\section{Box 1. Key Features of Effective Out-of-Court Restructuring Mechanisms}

- Government involvement-The restructuring mechanism should be market-driven, with banks forming creditor committees and acting as lead creditors. However, administrative support and endorsement by the government can be helpful (Laryea, 2010). Support from the banking supervisor is also important. ${ }^{1}$ In addition, the government can incentivize participation by offering financing, which can play an important role when there are market failures that can prevent private creditors from providing adequate financing (e.g. when banks are capital constrained). An example of this is the U.S. government's support for auto companies when they were undergoing reorganization procedures during the GFC (see Grigorian and Raei, 2010).

- Creditor participation - Informal restructuring mechanisms to resolve financial distress are only effective when all significant financial creditors participate actively. In informal restructurings, participation is entirely voluntary (Japan), but the effectiveness of this approach can be enhanced if lenders adhere to a general protocol of debt restructuring principles. Such protocols are often based on the INSOL Principles for multi-creditor workouts, as was the case in Thailand during the AFC ("Bangkok framework"). Another method to foster participation is encouraging creditors to adhere to a master restructuring agreement. ${ }^{2}$

- "Carrots and sticks"-The effectiveness of informal restructuring mechanisms can be enhanced through incentives that foster participation. The most important of them is a credible threat of bankruptcy that can lead to debt enforcement or liquidation, which incentivizes debtors and creditors to negotiate in good faith (see Mako, 2001; and Claessens, 2005). Other tools include tax incentives for the debtor and creditors (e.g. tax benefits and stamp duty reductions in Thailand), regulatory incentives for bank creditors, and monetary sanctions in case of undue delays in the negotiations.

- Assistance by restructuring experts - The informal restructuring mechanism can be supported by restructuring experts. ${ }^{3}$ Their role is to analyze the viability of enterprises and draw up restructuring plans for consideration by debtors and creditors. In addition, disputes in the context of the restructuring can be resolved through mediation or arbitration, with the assistance of legal experts.

- Dissenting creditors - In an out-of-court procedure there is always a possibility that dissenting creditors could hold out. If a master restructuring agreement has been signed, it would typically commit all creditors to accept the majority decision. If there is no master agreement or if the requisite majorities are not met, an option should be provided to initiate a fast-track insolvency case ("pre-pack") to obtain prompt judicial confirmation of a proposed restructuring plan that binds all creditors (Korea, Japan).

- Stand-by agreements - Out-of-court restructuring requires that participating creditors and the debtor commit to abstain from taking actions that alter the relative positions of creditors, including taking security or starting enforcement actions against the debtor. If there are creditors who do not agree with this approach, it may be necessary to resort to judicial intervention to obtain a stay of creditor actions, either under formal reorganization or hybrid restructuring procedures.

\footnotetext{
${ }^{1}$ The corporate debt restructuring committee (CDRC) supported by Bank Negara Malaysia is a good example for this. See www.cdrc.my for more information.

${ }^{2}$ Examples in the region of this approach include the Corporate Debt Restructuring Agreement in Korea and the Intercreditor agreement in Thailand.

${ }^{3}$ Where such expertise is not available locally, international experts can be brought in. This was a prominent feature in several countries during the AFC (Indonesia, Korea, Thailand).
} 
Efficient out-of-court restructuring for SMEs may require a more standardized approach. Large numbers of distressed SMEs can create immense pressure on court systems, even where a simplified treatment of smaller claims exists. A special out-of-court restructuring regime for SMEs can help avoid such an outcome, and several countries in the region already have them in place (Japan, Korea, Malaysia, Thailand). These mechanisms are less complex than those designed for large corporates and often feature support to entrepreneurs by the government through advisory services and financial programs. ${ }^{7}$ However, the capacity to provide such support may need to be scaled up if there is a sharp increase in insolvency cases. A more aggressive approach could be based on standardized solutions (i.e. restructuring plans which are adjusted to reflect some basic characteristics of each debtor), which can accelerate the restructuring of elevated numbers of SMEs. On the spectrum of restructuring approaches, standardized solutions fall between tailor-made solutions and across-the-board measures, such as general moratoria or general debt forgiveness. ${ }^{8}$ They can be adapted to the circumstances of each case and offer a less precise, but simpler and less costly solution than restructurings based on individualized viability analysis. ${ }^{9}$

Effective insolvency frameworks are necessary to tackle more complex cases. Special, temporary out-of-court restructuring mechanisms can facilitate the restructuring of viable enterprises without overwhelming the court system. However, court-led insolvency procedures are also necessary to allow for the reorganization of viable enterprises that require more extensive restructuring. Countries should assess their insolvency systems against international standards to identify gaps for improvement. ${ }^{10}$ Some of the features of effective insolvency systems that would be most relevant in the context of this crisis include the following:

- Debtor-in-possession (DIP) reorganization - Debtors should be allowed to continue managing their businesses while in reorganization. This creates a strong incentive for debtors to use the process at an early stage, instead of delaying until the only option available is liquidation. Most Asian systems have incorporated debtor in possession proceedings, but there are exceptions (India) and also cases where practical implementation could be improved (China).

- Post-petition finance-One of the main reasons for the failure of reorganizations is the lack of financing for enterprises that have entered insolvency proceedings. Enabling such financing requires giving priority to the providers of fresh funds, with safeguards for existing creditors. Many Asian countries give priority to post-petition financing (China, India, Japan, Korea), but

\footnotetext{
${ }^{7}$ Because of prohibitive costs, SMEs are generally unable to prepare detailed viability reports and restructuring plans as large firms under insolvency procedures do. Hence, governments often step in to offer technical support to smaller firms in distress.

${ }^{8}$ Across-the-board measures are generally not recommended, as they fail to discriminate between viable and nonviable enterprises, and their fiscal cost tends to be very significant (Laryea, 2010).

${ }^{9}$ For example, in Iceland during the GFC, the debt of distressed SMEs that could evidence future positive cash flow was written down to the value of the discounted cash flows or to the value of their assets in a potential liquidation. This reduced SMEs' debts to sustainable levels and offered creditors a better outcome than delayed liquidations in an overburdened court system.

${ }^{10}$ The relevant insolvency standards are the World Bank Principles for Effective Insolvency and Creditor Rights Regimes and the Recommendations of the UNCITRAL Legislative Guide on Insolvency Law.
} 
others do not (Indonesia) or lack specific rules (Vietnam). Legislation is necessary but not sufficient as banks and other financial institutions must be incentivized to provide this financing. Even with this priority claim, the regulatory framework can discourage them from lending to companies undergoing reorganization (see next section). Less constrained, specialized distressed assets funds increasingly provide this financing, especially in large markets, such as China and India, which have the scale to attract these funds.

- Hybrid restructuring procedures-Hybrid insolvency procedures combine informal negotiations between debtors and creditors and minimal judicial intervention in the form of a stay of creditor actions and the confirmation of plans. Procedures include "pre-packaged" and "pre-arranged" plans that benefit from fast court approval if agreed with creditors (already in use in Japan, Korea, the Philippines, and to a lesser extent, in China), as well as preventive insolvency procedures, e.g. those put in place after the European crisis by France, Italy, Spain, and more recently, the UK. These procedures reduce the intervention of the courts, allowing the insolvency system to deal with other cases. For example, intensive use of pre-packaged and pre-arranged plans can be equivalent to a five-fold increase in judicial capacity. ${ }^{11}{ }^{12}$ Some Asian countries, such as Indonesia, India, and Thailand, would benefit from the use of prepackaged plans to accelerate corporate debt restructuring. Other countries with the common law tradition could improve the features of their schemes of arrangement by enabling a wide stay of creditor actions and cross-class cramdown of plans (Australia, Sri Lanka). ${ }^{13}$

- Simplified regime for micro- and small enterprises - The growing trend towards simplified insolvency procedures for SMEs reflects the problem that general insolvency procedures are often too complex and costly for their needs (see Bergthaler et al., 2015). Simplification and cost-reduction may be necessary for SMEs as insolvency procedures were designed primarily for larger enterprises in mind. In Asia, Japan, Singapore, Thailand, and Korea have introduced special procedures for small enterprises. Australia is in the process of doing so.

- Specialization of judges and insolvency professionals-Increasing specialization of the judiciary, including through the creation of dedicated insolvency courts as in China, India, Korea and Thailand, should be part of the long-term strategy to strengthen insolvency systems. For most countries, building a robust insolvency profession is still a work-in-progress. India has established a strong structure for the regulation and qualification of insolvency professionals, and other countries could follow suit.

- Use of technology and data - Greater use of technology in the insolvency process, such as through electronic case management; electronic communications; virtual meetings and hearings, can also help increase efficiency and capacity. Countries should also devote

\footnotetext{
${ }^{11}$ A pre-packaged plan has already the support of the required majority of creditors. A pre-arranged plan has been negotiated with the major creditors but need to gain further support.

12 Based on published information (The Deal Pipeline and FTI consulting, Inc.), the average ordinary reorganization procedure in the US during the period 2011-2018 lasted 504 days. Pre-packaged reorganizations for the same period lasted only 77 days on average. Pre-arranged bankruptcy cases lasted an average of 219 days.

${ }^{13}$ A "scheme of arrangement" is an agreement, confirmed by a court, that modifies the debt or capital structure of a company. Cross-class cramdown refers to the possibility of having a reorganization plan adopted even if one or several of the creditor classes votes against the plan, provided that procedural and substantive safeguards are respected.
} 
resources to the collection and analysis of insolvency data to help assess performance and support the design of reforms to address remaining shortcomings (Garrido et al., 2019).

The insolvency regime will also perform the function of liquidating non-viable enterprises. However, at this stage of the crisis, the emphasis should be on the reorganization of viable enterprises as there is typically a narrow window of opportunity for reorganization, and the liquidation of viable enterprises has high economic costs (Bernstein et al., 2019a and 2019b).

With these broad principles as a guide, countries in Asia and the Pacific should take further steps now to strengthen their insolvency frameworks. While many countries now have modern court-based insolvency procedures in place, effective out-of-court restructuring mechanisms are currently only available in some economies (Table IV.1). Malaysia and Korea have preserved the special restructuring mechanisms put in place during the AFC, while Japan has over the years developed robust informal restructuring practices. These countries can use their established restructuring mechanisms to increase the capacity of their insolvency systems if needed. Indonesia and Thailand should consider restoring and upgrading the special restructuring frameworks they used on a temporary basis during the AFC. Other countries can take steps to strengthen informal restructuring mechanisms they have put in place in more recent periods (e.g., India and China).

Table IV.1. Insolvency Regimes in Asia and the Pacific: Available Tools for Restructuring and Reorganization

\begin{tabular}{|c|c|c|c|c|c|}
\hline & \multicolumn{2}{|c|}{ Out-of-Court } & \multirow{2}{*}{$\begin{array}{c}\text { Hybrid } \\
\text { Hybrid } \\
\text { Restructuring/ } \\
\text { Pre-packs }\end{array}$} & \multicolumn{2}{|c|}{ In-Court } \\
\hline & $\begin{array}{c}\text { Enhanced } \\
\text { Restructuring }\end{array}$ & $\begin{array}{l}\text { SME debt } \\
\text { restructuring }\end{array}$ & & Reorganization & $\begin{array}{l}\text { SME Simplified } \\
\text { Reorganization }\end{array}$ \\
\hline Australia & & & $\checkmark$ & $\checkmark$ & \\
\hline Bangladesh & & & $\checkmark$ & $\checkmark$ & \\
\hline China & $\checkmark$ & & $\checkmark$ & $\checkmark$ & \\
\hline Hong Kong SAR & & & $\checkmark$ & & \\
\hline India & & & & $\checkmark$ & \\
\hline Indonesia & & & & $\checkmark$ & \\
\hline Japan & $\checkmark$ & $\checkmark$ & $\checkmark$ & $\checkmark$ & $\checkmark$ \\
\hline Malaysia & $\checkmark$ & $\checkmark$ & $\checkmark$ & $\checkmark$ & \\
\hline Philippines & $\checkmark$ & & $\checkmark$ & $\checkmark$ & \\
\hline Singapore & & $\checkmark$ & $\checkmark$ & $\checkmark$ & $\checkmark$ \\
\hline Korea & $\checkmark$ & $\checkmark$ & $\checkmark$ & $\checkmark$ & $\checkmark$ \\
\hline Sri Lanka & & & $\checkmark$ & $\checkmark$ & \\
\hline Thailand & & $\checkmark$ & & $\checkmark$ & $\checkmark$ \\
\hline Vietnam & & & & $\checkmark$ & \\
\hline
\end{tabular}

For countries where insolvency practice is minimal, a different restructuring approach is required. Filling all the gaps of the legal and institutional framework will generally not be possible in time to address cases of corporate financial distress caused by the pandemic. Countries without a functioning insolvency system should instead concentrate on supporting the solvency of strategic enterprises and setting up special restructuring mechanisms for both larger companies and SMEs. A longer-term strategy would require the revision of insolvency laws and the strengthening of the courts and insolvency profession. 


\section{B. Ensuring Adequate Financing to Support Corporate Restructuring and the Recovery}

Successful corporate restructuring is critically dependent on the availability of fresh financing. Banks will have to play a critical role in providing such financing given their still dominant role in most financial systems in Asia and the Pacific, especially in emerging and lowincome economies.

Authorities should use the flexibility built into existing regulatory and supervisory frameworks to avoid a procyclical credit contraction in the pandemic (IMF and World Bank, 2020a). Supervisors have encouraged banks to work with affected borrowers to prudently restructure loans for viable firms and individuals impacted by the crisis. They can clarify how banks should assess loan performance in the current environment, prudentially treat restructured loans, and estimate credit losses, building on guidance issued by international standard-setting bodies. India has provided supervisory guidance regarding asset classification and loan provisioning to facilitate restructuring and resolution of corporate loans. In Korea, banks have bilaterally rescheduled principal and interest on loans amounting to about 4 percent of GDP (through August, 2020). Such bilateral loan rescheduling based on commercial criteria tends to be more targeted and less prone to moral hazard and credit misallocation than "blanket" moratoria. Supervisors should also intensify the on-site monitoring of asset quality to ensure that banks are prudently classifying loans and provisioning appropriately.

Easing of macroprudential policy settings may also be an appropriate response. This can help avoid an undue tightening of financial conditions for firms that could amplify the impact of the pandemic shock through adverse feedback interactions between the real and financial sectors (IMF 2020). Where appropriate, relaxing sectoral tools can help reduce financial distress and facilitate debt restructuring. In Asia and the Pacific, several jurisdictions have already eased policy settings by increasing loan-to-deposit ratios (Korea), reducing the required stable funding factor for short-term loans to individuals and businesses under the net stable funding ratio (Singapore), excluding central bank reserves from the calculation of the leverage ratio (Japan), and lowering the liquidity coverage ratio (Korea, Thailand).

Beyond these measures, ensuring that banks have capital well above regulatory minimums will be critical to support corporate restructuring and new lending. Experience from past crises suggests a positive link between bank capitalization and credit growth. ${ }^{14}$ Many of the region's banks entered the pandemic in a strong financial position as regulatory reforms following the GFC have led to marked increases in the quality and quantity of capital and liquidity (Table IV.2). However, a few countries were already confronting asset quality problems before the pandemic hit (China, India). Amid heightened uncertainty about pandemic-induced credit losses, banks in the region may now face broader pressures to conserve capital by curtailing corporate lending.

\footnotetext{
${ }^{14}$ For instance, Cohen and Scatigna (2016) document how better capitalized banks in advanced and emerging economies lent more in the aftermath of the GFC.
} 
Table IV.2. Capital Adequacy and Liquidity in Banking Sector: Selected Economies

\begin{tabular}{c|c|c|c|c}
\hline & \multicolumn{2}{|c|}{ Tier 1 Capital Ratio } & \multicolumn{2}{c}{ Liquid Assets to Short Term Liabilities } \\
\cline { 2 - 5 } & GFC (2008) & COVID-19 (2019) & GFC (2008) & COVID-19 (2019) \\
\hline Japan & 9.1 & 15.1 & 43.31 & 47.8 \\
\hline Australia & 7.1 & 13.1 & 27.5 & 34.2 \\
\hline Korea & 8.8 & 12.9 & 102.5 & 101.22 \\
\hline Singapore & 11.5 & 15.3 & 77.9 & 73.8 \\
\hline Hong Kong SAR & 11.2 & 18.5 & 50.0 & 176.1 \\
\hline China & 10.1 & 11.8 & 42.23 & 55.3 \\
\hline India & 9.1 & 14.7 & 48.3 & 22.9 \\
\hline
\end{tabular}

1/ as of 2009 Q3 2/ as of 2017 Q4. 3/ as of end-2010.

Sources: Financial Soundness Indicators and Haver Analytics.

A forward-looking diagnostic of potential loan impairments can help gauge possible capital needs of banks. Supervisors in many jurisdictions in Asia and the Pacific already conduct regular systemwide stress tests. These may need to be updated to reflect some of the specific characteristics and the intensity of the COVID-19 shock, including differentiated impacts across sectors and the prospect of depressed bank profits due to "low for even longer" interest rates in the aftermath of the crisis (Carletti et. al., 2020). The results from such pandemic stress tests will help reassess the risk that banks that currently appear solvent may need additional capital, both to meet prudential requirements and maintain adequate lending for the recovery.

Banks can use existing capital buffers to absorb possible losses from restructuring loans while maintaining lending. Prudential capital buffers under the Basel III framework are designed to be used in times of stress. ${ }^{15}$ Counter-cyclical capital buffers are most suited for release but in Asia and the Pacific only Hong Kong SAR had a non-zero buffer at the onset of the pandemic. ${ }^{16}$ While the capital conservation buffer (CCB) is not a releasable tool, banks can make use of the buffer on a temporary basis. However, even where regulators encourage banks to use the $\mathrm{CCB}$ or provide other temporary relief from capital requirements, banks may be reluctant to use these margins knowing that they will eventually have to return to their higher, steady state level of capital ratios (Blank et. al., 2020).

Consideration should be given to temporarily restrict capital distributions to preserve the level of capitalization in banking systems (Awad et. al., 2020). During times of stress, retained earnings are often a key channel for banks to increase capital (Cohen and Scatigna, 2016). The Basel standards already limit distribution of dividends, share buybacks, and discretionary staff bonus payments when capital buffers are drawn down. However, the uncertainty surrounding the impact of the pandemic shock provides an argument to restrict distributions even earlier, as the benefits from avoiding a credit squeeze due to capital shortages are likely to outweigh any costs of temporary overcapitalization (Blank et. al., 2020). Restrictions on capital distributions should apply to all banks to avoid stigma. Among the major economies in Asia and the Pacific, Australia, India, Korea, Singapore, Thailand, and Vietnam have issued recommendations or directives limiting or deferring dividend payouts following the COVID-19 shock.

\footnotetext{
${ }^{15}$ Where liquidity is a binding constraint for lending, liquidity buffers in domestic and foreign currency can also be released, if needed, in accordance with the Basel Liquidity Coverage Ratio (LCR) standard or other domestic liquidity requirements (IMF, 2020).

${ }^{16}$ Hong Kong SAR reduced its buffer from 2 to 1 percent in March 2020.
} 
The authorities can also provide incentives for banks to raise additional private capital. In times of stress, banks and investors are often reluctant to consider capital increases because financial markets tend to react negatively to new equity offerings. ${ }^{17}$ Stigma can also be a concern. Authorities can try to address these collective action problems, using their convening power and supervisory dialogue to nudge banks to proactively increase capital buffers. ${ }^{18} \mathrm{~A}$ more forward-leaning approach would be to provide financial incentives such as matching public capital contributions at a low cost to compensate banks for the higher cost of raising private capital. ${ }^{19}$ Tax incentives can also be used to decrease the cost of equity financing, for instance, by allowing banks to deduct a notional return (interest) on their equity from taxable income. ${ }^{20}$

\section{A publicly funded bank recapitalization fund can serve as a useful backstop if capital} cannot be immediately raised from private sources. The use of public funds for bank recapitalization should generally be considered as a last resort when there is a risk to financial stability or when a market failures limit timely access to private capital (Dobler et. al., 2020). Where access to private capital is temporarily interrupted by the uncertain pandemic environment, setting up a public fund that solvent banks can tap preemptively to raise capital could be considered. Such an equity backstop can accelerate the replenishment of capital buffers and support confidence. In Asia, during the GFC, the Korean authorities set up two largely publicly funded vehicles to offer banks and other financial institutions access to fresh capital in the form of preferred stocks, hybrid bonds, or subordinated bonds, conditioned on commitments to sustain lending to the real sector (Box 2). ${ }^{21}$ The United States also created a public capitalization vehicle through the Capital Purchase Program (CPP) under the Troubled Asset Relief Program (TARP). However, in all cases, public capital injections should be subject to safeguards that address concerns of moral hazard, conflict of interest, and taxpayer protection (see Dobler et. al., 2020).

Institutions other than banks, such as special investment vehicles, can also play an important role in support of corporate restructuring. In some economies non-bank financial institutions play a significant role in the provision of corporate credit and many of the earlier considerations for banks apply as well. In countries with more developed capital markets, investment vehicles can help promote a market for impaired assets (such as non-performing loans, junk bonds, and real estate funds). They can also step in to acquire distressed firms for turnaround (buyout funds), thereby complementing creditor-led restructuring frameworks. A

\footnotetext{
${ }^{17}$ Corporate finance theory attributes this behavior to information asymmetries (see Calomiris, 2013, and Majluf and Myers, 1984).

${ }^{18}$ In the run-up to the GFC, the U.S. authorities called on financial institutions - privately and publicly-to raise capital, which led to some (limited) equity injections (Jester et. al (2018)).

${ }^{19}$ This option was considered by the U.S. administration when designing the Capital Purchase Program (CPP) under the Troubled Asset Relief Program (TARP) but ultimately dismissed because the crisis had advanced to the point that banks were essentially shut out of the market for fresh equity (Jester et. al (2018)).

${ }^{20}$ Such allowances for corporate equity have been introduced in a number of countries (Belgium, Brazil, Italy, Latvia) and there is evidence that they have contributed to lower banks' debt-equity ratio by narrowing the gap in the tax treatment of debt and equity (Celerier et al. (2019)).

${ }^{21}$ These targeted capital injections are seen to have contributed to stabilizing the banking system at the time (Jester et. al (2018)).
} 
conducive regulatory environment and operational flexibility is key to encouraging the emergence of such players. ${ }^{22}$

\section{Box 2. Korea's Bank Recapitalization and Financial Stabilization Funds}

During the GFC, the Korean authorities preemptively set up two largely publicly funded vehicles for the capitalization of banks and other financial institutions, subject to commitments to maintain corporate lending.

- Bank Recapitalization Fund: In Dec 2008, the authorities established a conditional recapitalization program to help banks enhance their capacity to absorb potential loan losses from the downturn caused by the GFC. The maximum size of the fund was set at 20 trillion won (1.7\% of GDP), financed by loans from the Bank of Korea (10 trillion won), the Korea Development Bank (KDB) (2 trillion won), and the sale of secondary asset-backed securities to private financial institutions ( 8 trillion won). Unlike bank recapitalizations during the AFC, the fund did not acquire common shares that would cause stock dilution and disincentivize bank participation. Instead, banks could raise capital by selling preferred stocks, hybrid bonds, and subordinated bonds to the fund within a pre-set ceiling based on their asset size. Access for banks was conditional upon commitments (set out in an MOU) to support to real economy through (i) the extension of credit lines to SMEs and (ii) participation in debt-to-equity swaps of firms under workout programs. In March 2009, the fund made its first and only purchase, with a total of 4 trillion won of hybrid and subordinated bonds issued by 8 banks. With Korea's fast recovery from the GFC, no further purchases were executed and the Bank of Korea and KDB recovered their loans in 2014.

- Financial Stabilization Fund: In May 2009, Korea's parliament approved the institutional settings for a temporary "Financial Stabilization Fund" (FSF). The FSF was conceived as a comprehensive and flexible tool of "last resort" to safeguard the financial sector's soundness. The fund, managed by the KDB, was empowered to directly issue government-guaranteed bonds up to a ceiling approved by the National Assembly for its funding. Eligible beneficiaries included all banks, non-bank financial institutions, and financial holding companies. The Fund had flexibility to deploy a wide range of financial tools to support the financial sector, including equity purchases, loans, and loan guarantees. Similar to the bank recapitalization fund, support was to be conditional on commitments by beneficiaries to support lending to the real sector. Ultimately, the FSF did not enter into operation owing to the fast recovery of the Korean economy. The legal authority under which the FSF was set up was led to expire at the end of 2014.

\section{Pivoting to Equity Support for Non-Financial Firms}

\section{Extending equity support to non-financial firms can complement the liquidity assistance} that is already being provided to address the crisis. As noted earlier, private investors may not be able or willing to come forward now and provide sufficient financing to avoid large-scale bankruptcies. In these circumstances, public equity support schemes may be needed to temporarily fill the gap, supplementing liquidity support. Equity, or equity-like, support for viable firms has the advantage of immediately strengthening balance sheets, and expand firms' capacity to borrow and invest until access to private capital is restored. Equity intervention also allow governments to "capture some of the upside" gains from their interventions.

\section{Public equity support should be targeted at firms and industries most affected by the pandemic and with positive externality benefits. In addition to tax and regulatory reforms, policymakers could utilize public resources directly for equity injections, with adequate}

\footnotetext{
${ }^{22}$ During the AFC, Korea created of a number of special vehicles to facilitate corporate restructuring such as a corporate restructuring company (vulture fund), corporate restructuring fund (that invested in SME securities), and corporate restructuring REITs (for investment in real estate assets) by easing investment and operational regulations.
} 
safeguards. For example, Korea established a "Key Industry Stabilization Fund" in May, managed by the Korean Development Bank and co-funded by private investors to provide conditional equity support to strategic sectors hit hard by the pandemic, such as airlines and the shipping industry. The EU's proposed Recovery Fund at considered a solvency support instrument managed by the European Investment Bank to support equity investment in economically viable firms (EC, 2020). Similarly, countries in Asia and the Pacific could consider allocating a portion of their public investment program to establishing a time-bound "Pandemic Equity Fund" that, alongside the private sector, could invest in companies looking to retool. This could be in the same spirit as the Asset Management Companies established after the Asian financial crisis, such as KAMCO in Korea or IRCJ in Japan, to stabilize and restructure the corporate sector. Over time, these funds also helped to deleverage the corporate sector and jumpstart a private-led market for distressed debt and assets.

To be effective, public equity funds would require strong governance, including a clear mandate, high transparency, and a clear exit policy. Given the risks to public funds and the need to avoid costly delays in corporate restructuring, public interventions should clarify upfront selection criteria for distressed but viable firms, specify any broader economic and social goals to be pursued, and feature a high degree of transparency and governance, especially with regard to valuation criteria. This would also include conditions such as caps on executive compensation and restrictions on dividends and share buybacks. Interventions should be time-bound and have a clear commercial mandate to maximize recovery value. This will protect taxpayer resources and avoid warehousing bad assets. On the seniority of the public sector's claims, policymakers will need to weigh the tradeoff between limiting fiscal risks through greater protection in case of insolvency and discouraging more junior, private financing later. Accepting pari passu protection with other investors would allow the government to leverage the financing and expertise of the private sector while still maintaining upside gains. Past interventions have also allowed owners to repurchase shares at a premium, such as through equity warrants.

The provision of equity support by governments would require a shift in the government mindset from that of a creditor looking to recover principal to that of a portfolio equity investor serving as a "venture capitalist of last resort". Authorities would have to be willing to take on additional risk and accept some losses in exchange for longer-term or broader social gains (Mazzucato, 2011; Stein, 2020). As some ventures are likely to fail, the performance of the public funds should be evaluated based on an overall ex-post rate of return of the portfolio rather than individual investments. This will incentivize long term capital gains and protect public agencies from political criticism on individual losses.

Where the social and economic cost of mass SME insolvencies is high, equity-like support tailored to small firms could also be considered (IMF, 2020b). For incorporated SMEs, these measures could include non-voting preferred shares or convertible bonds with long repayment periods that would provide funds upfront and whose conversion to equity would be conditional on the firm's performance. In return for lengthening repayment and not assuming managerial control, the public sector could receive a share of the upside through dividend payments or 
temporarily higher future corporate tax payments. ${ }^{23}$ For all types of SMEs, including those that are not incorporated, hybrid financing through subordinated loans or profit participation loans (where interest payments depend on the profits of the firm) could also be considered. Germany and other European countries have experience with the use of these instruments, which also require adequate reporting and controls. As with support for larger firms, strong governance arrangements would be critical to avoid prolonging the life of nonviable SMEs. This could include industry-level benchmarking of key financial ratios, as was done in Italy as an early warning guidance for more timely restructuring, closer monitoring and reporting requirements for firms receiving state support, as well as penalties for misreporting and fraud.

In the recovery phase, firms in Asia and the Pacific will also need to mobilize more private equity to reduce debt overhangs and adjust to the post-pandemic world. As firms emerge from restructuring and look to adjust their business model and expand operations, the need for risk capital is likely to increase, especially for firms unable to take on more leverage. Equity will be needed to absorb idle labor, shift resources into more productive areas, and disseminate new technology and practices. Even before the pandemic, startup rates in Asia and globally have been on the decline, constraining firm dynamism and productivity growth (IMF, 2018). Expanding the supply of private equity would facilitate this resource reallocation and deleveraging. The public sector will also need private equity to take over eventually its holdings in supported firms.

\section{The relative lack of risk capital in Asia and the Pacific may be a constraint in this} structural transformation of the corporate sector. Asia has a large pool of domestic savings, but much is invested in low-yielding bank deposits, government securities, or real estate. Equity markets are generally smaller than those in the U.S. and Europe. While the institutional investor base in Asia has expanded, the financial system remains bank-centered with limited development of markets for longer-term and riskier capital funding capital funding.

Thus, policies in the recovery phase should seek to promote the raising of new corporate equity. This will allow a greater role for the market to differentiate between viable and nonviable firms (providing a useful signal to banks) and avoid the "zombie" problem that has plagued previous corporate restructuring efforts in Asia and elsewhere. (Caballero et. al. 2008, BIS, 2020). While broader capital market reforms will take time, authorities can take a few immediate measures to encourage the issuance of equity:

- Eliminate the tax bias against equity - As is the case globally, tax systems in Asian and the Pacific allow for interest deduction on debt but not on dividend payments on equity. Eliminating the bias in the tax code by removing the interest deduction would be the preferred solution. Alternatively, a temporary subsidy to equity issuance can help support a healthier capital structure, albeit at a fiscal cost. For example, Belgium, Italy and Turkey have introduced an allowance for corporate equity (ACE) that adds a deduction for the normal return on equity, alongside the deduction for interest (IMF, 2016).

\footnotetext{
${ }^{23}$ For example, Boot et. al. (2020) have suggested the funds could also target support to SMEs by offering cash to firms in exchange for a temporary increase in future corporate taxes conditional on the firm making profits. Blanchard, Philippon, and Pisani-Ferry (2020) have suggested partial loan guarantees, government debt to equity conversions, and temporarily higher future corporate taxes to assist the corporate sector.
} 
- Provide incentives for debt to equity conversions and subsequent disposal of equity holdings-Banks may be reluctant or are unable to convert debt to equity because of either restrictions on owning nonfinancial companies, time limits for disposing the converted equity, and/or a higher capital charge for holding equity (Daniel et. al., 2016). Supervisors could reduce holding limits or temporarily lower the capital charge on debt-equity conversions, while tax authorities could eliminate the tax on debt-equity swaps to encourage banks to accept losses upfront and make this substitution. After the Asian financial crisis, several countries introduced tax and regulatory incentives for debt-equity swaps and other institutional improvements to promote issuing equity. Currently, the Financial Services Agency (FSA) in Japan is considering a proposal to relax the 5 percent limit on equity ownership in nonbank companies to encourage regional banks to engage more directly in assisting companies. Ensuring proper valuation and a return to normal capital charges on these equity holdings would provide strong incentives for their timely disposal and avoid moral hazard risks.

- Simplify regulations and reduce costs for startups-To promote entrepreneurship and technology diffusion, reforms could prioritize reducing the cost or providing incentives for startups. For example, regulators could reduce the number of procedures, time and minimum paid-in capital requirements associated with starting a business. Tax incentives could be provided for job hires by startups. Addressing corporate governance gaps would improve investor confidence in financing startups.

\section{Conclusions}

The policy response to the COVID-19 shock will have to evolve as the economies in Asia and the Pacific stabilize and enter the recovery phase. Much of the initial support for firms focused on the provision of liquidity to withstand the cash-flow squeeze arising from the sudden drop in revenues. As economic activity recovers, policymakers will need to reassess their policy tradeoffs between providing liquidity vs. solvency support and address the lasting consequences of the pandemic for firms, including growing debt overhangs and fundamental changes in firms' operating environment.

In the pandemic phase, avoiding a premature withdrawal of policy support remains an immediate priority. The incipient recovery is still fragile and uneven across countries, and there remains considerable uncertainty about the course of the pandemic and the availability of effective therapeutics and vaccines going forward. Hence, policymakers should err on the side of caution and begin phasing out liquidity support only once the recovery is well entrenched.

At the same time, authorities should move to create an environment that facilitates the efficient reallocation of resources into growth sectors. This requires action on three complementary fronts: reinforcing private debt resolution frameworks to "flatten the insolvency curve" and prevent excessive insolvencies; ensuring that adequate financing is available to support corporate restructuring; and facilitating access to risk capital for existing and new firms.

Coordination among various stakeholders will be important for effective corporate restructuring. Continuous monitoring of the impact of the crisis and the effectiveness of implemented measures will help adjust the policy response based on observed outcomes. This 
will require close coordination across different agencies and branches of government. Where insolvencies arise on a large scale, establishing a special government entity to coordinate the various public functions can help align and achieve social goals. Consideration can also be given to creating a political entity, similar to the tripartite commissions of government, business, and unions formed in previous crisis, that can build a dialogue and consensus on necessary reforms.

Overall, the measures suggested in this paper for the second phase of the policy response would promote a stronger recovery by improving the business environment and increasing resilience. More robust insolvency frameworks would not only help address the post-pandemic debt overhang but also deliver longer term benefits by enhancing the capacity of economies in Asia and the Pacific to adjust more effectively to negative shocks. Similarly, corporate finance reforms that lead to a stronger "equity culture" will help expand financing for innovative startups and their growth, thus enhancing the overall dynamism of the region's economies going forward. 


\section{Annex I. Policy Responses to the PAndemic Shock in Asia ANd the PaCific 24}

Monetary and financial sector policies. Most jurisdictions in Asia and the Pacific eased monetary policy, but with conventional policy space limited, many also resorted to quantitative easing.

- Policy rate cuts averaged 60 bps for Asia and the Pacific, below the world average, with substantial differences across countries: Advanced economies (AEs) in the region cut policy rates by only $35 \mathrm{bps}$, reflecting the proximity of policy rates to the effective lower bound, while emerging market economies (EMs) cut 60 bps and low-income countries (LICs) 135 bps.

- Direct liquidity support to banks was provided by half of Asia and Pacific countries, totaling 4.7 percent of regional GDP, below the world average. Quantitative easing tools (e.g., introduction of standing facilities, cuts in reserve requirements, or "funding-forlending" schemes) were used by a larger share of AEs ( 86 percent) than EMs (50 percent), but the volume of liquidity support was larger for EMs (5.6 percent of GDP) relative to AEs (1.3 percent of GDP).

- Monetary operations targeting financial markets by purchasing government or private debt (e.g. mortgage-backed-securities, commercial paper, high-yield debt, etc.) were undertaken mostly in Asian AEs, where firms rely more on markets for funding. One-quarter of EMs purchased government debt in primary markets, raising monetization risks.

- Special Purpose Vehicles (SPVs) have been set up by the Korean authorities to support banks and firms (especially SMEs) by purchasing loans or corporate securities. SPV balance sheets are funded in part by the central bank and/or investors, with the government (through a policy bank) providing an equity contribution to absorb SPV losses. ${ }^{25}$

- Macroprudential policy easing. This involved reducing the counter cyclical capital buffer in Hong Kong SAR, which had been built up earlier in response to domestic real estate and credit booms. The setting of other types of macroprudential policies, such as reserve requirements or loan-to-deposit/value ratios were also loosened (in some cases temporarily) by a number of countries (e.g. New Zealand, Korea).

- Fiscal policy. Support provided in Asia and the Pacific in 2020 was sizeable but below the global average, with on-budget support (4.7 percent of GDP) roughly matched by off-budget quasi-fiscal measures (4.4 percent of GDP).

- Direct fiscal support helped avoid a collapse in aggregate demand and protected employment and worker-employer relationships, but contributed to a sharp rise in budget deficits. The scale of support varied substantially across Asia, reflecting differences in fiscal

\footnotetext{
${ }^{24}$ Policy responses considered up to end-July 2020.

${ }^{25}$ See Kang and Rhee (2020) for a broader discussion of this policy tool.
} 
space, with AEs providing the most support (9.8 percent of GDP), followed by EMs (3.6 percent of GDP) and LICs (1.8 percent of GDP).

- Quasi-fiscal support involving guarantees and other contingent liabilities that transferred risk to the government from banks incentivized them to continue lending to firms. This offbudget support was larger in AEs (17.7 percent of GDP) than on-budget support, but not in EMs and LICs.

- Public policy banks have been used by some governments to provide quasi-fiscal support through lending to firms and banks or purchases of corporate securities. They benefited from implicit guarantees from the government, which incurred contingent liabilities.

Policy interventions were unprecedented in Asia and the Pacific. The overall size of support was 4.5 percent of GDP on average for both direct ("on-budget") fiscal support and for quasifiscal ("below-the-line") measures (Table A.1). The scale of policy support varied with the level of countries' financial and economic development. Support by AEs was larger, reflecting their greater policy space, with direct and quasi fiscal support reaching about 10 and 18 percent of GDP, respectively. In contrast, for LICs direct support was just 2 percent of GDP, and quasi fiscal support was negligible. AEs also made greater use of available monetary policy space, with about 80 percent of central banks cutting policy rates and/or providing direct liquidity support to banks.

Table A.1. Scale of Policy Response in the Initial "Whatever-it-Takes" Phase

(Share of countries unless otherwise noted, from January to July 2020

\begin{tabular}{|c|c|c|c|c|c|}
\hline Policy Action & $\begin{array}{c}\text { Asia and Pacific } \\
\text { Total }\end{array}$ & $\begin{array}{c}\text { Asia and } \\
\text { Pacific AEs }\end{array}$ & $\begin{array}{c}\text { Asia and Pacific } \\
\text { EMs }\end{array}$ & $\begin{array}{c}\text { Asia and } \\
\text { Pacific LICs }\end{array}$ & World \\
\hline CBs cutting policy rate & $71 \%$ & $83 \%$ & $79 \%$ & $55 \%$ & $67 \%$ \\
\hline Size of policy rate cuts $1 /$ & $60 \mathrm{bps}$ & 35 bps & 60 bps & $135 \mathrm{bps}$ & $100 \mathrm{bps}$ \\
\hline CB liquidity to banks & $50 \%$ & $86 \%$ & $50 \%$ & $27 \%$ & $62 \%$ \\
\hline Volume of liquidity 2/ & $4.7 \% \mathrm{GDP}$ & $1.3 \% \mathrm{GDP}$ & $5.4 \% \mathrm{GDP}$ & $1.8 \% \mathrm{GDP}$ & $5.4 \%$ GDP \\
\hline CB liquidity to firms & $8 \%$ & $0 \%$ & $17 \%$ & $0 \%$ & $9 \%$ \\
\hline CBs easing liquidity req. & $52 \%$ & $40 \%$ & $44 \%$ & $71 \%$ & $40 \%$ \\
\hline Monetary finance of Gov. & $13 \%$ & $0 \%$ & $25 \%$ & $0 \%$ & $8 \%$ \\
\hline Direct fiscal support 2/ & $4.7 \% \mathrm{GDP}$ & $9.8 \% \mathrm{GDP}$ & $3.6 \% \mathrm{GDP}$ & $1.8 \% \mathrm{GDP}$ & $6.0 \%$ GDP \\
\hline Quasi-fiscal (guarantees) 2/ & $4.4 \% \mathrm{GDP}$ & $17.7 \%$ GDP & $2.2 \% \mathrm{GDP}$ & $0.1 \%$ GDP & $5.7 \%$ GDP \\
\hline
\end{tabular}

Notes: 1/ Basis points weighted by GDP 2/ Percent of weighted-average GDP Source: IMF Policy Tracker. 


\section{Annex II. The Financial Health of Non-Financial Corporations at the OnSET OF THE COVID-19 CRISIS}

\section{Nonfinancial companies (NFCs) in Asia and the Pacific entered the COVID-19 crisis with lower levels of profitability than at the onset of the GFC. Operating profits have declined} steadily in the major Asian economies in recent years and fell sharply in the first half of 2020 owing to the pandemic (Chart A.1). The share of firms with negative profits, measured by earnings before interest and taxes (EBIT), increased in 2019 across the region (except for the Philippines) and rose further in $2020 \mathrm{H} 1 .{ }^{26} \mathrm{In}$ most economies, this share now accounts for nearly 30 percent or more of all firms. Firms with negative profits tend to be smaller on average based on their asset size. ${ }^{27}$ Thailand and Vietnam are exceptions, where the increase in the number of firms with negative profits has been more broad-based, affecting both smaller and larger firms.

Chart A.1. Profitability of Non-Financial Companies in Asia and the Pacific
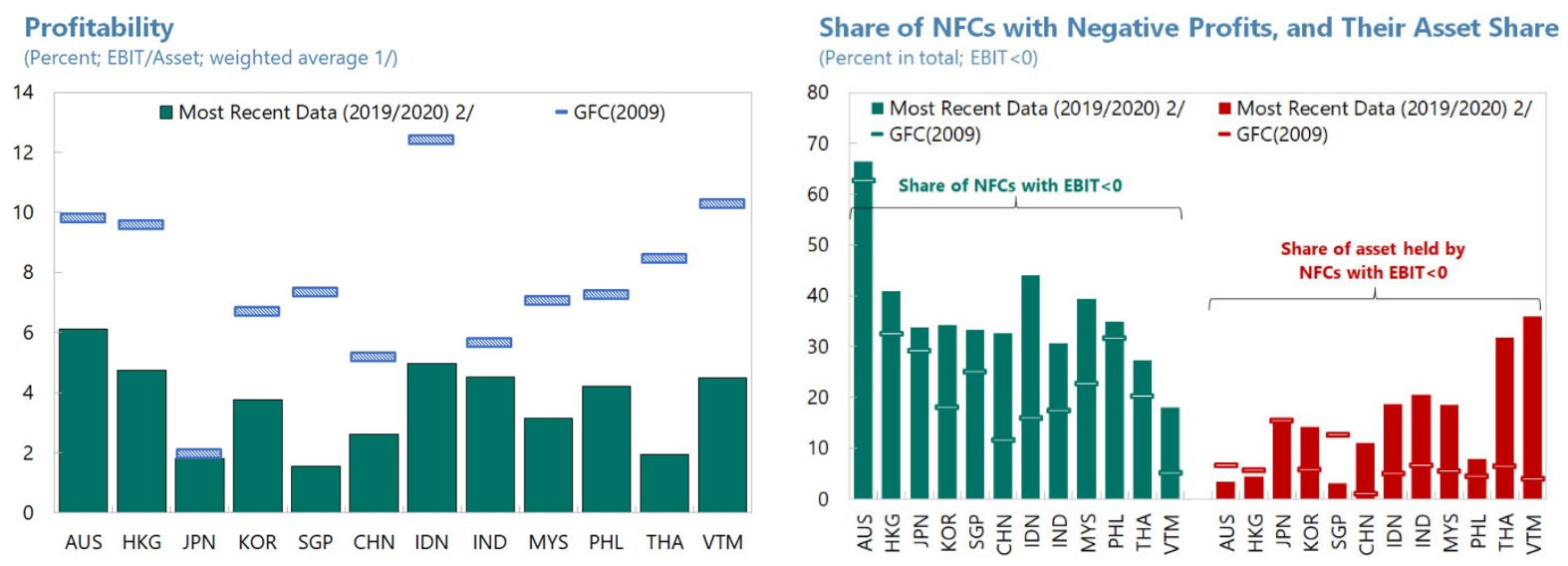

1/ Firms with market capitalization of at least US\$1 million. Averages weighted by total assets.

2/ The chart shows the most recent data, including 2019 for Australia, Hong Kong SAR, Singapore, 2020Q1 for Korea, China, India, Malaysia, Philippines, Thailand, and 2020Q2 for Japan, Indonesia, and Vietnam. India is based on fiscal year, which runs from April through March. Calendar year is used for other countries and jurisdictions.

Sources: S\&P Global Market Intelligence; and IMF staff calculations.

Leverage of NFCs in Asia and the Pacific rose considerably since the GFC and is now significantly above that of other regions (Chart A.2). The corporate debt-to-GDP ratio reached 119 percent of GDP in the first quarter of 2020, an increase of 35 percentage points relative to 2007. Much of this increase was driven by credit from banks and, in some instances, nonbanks (notably in China). Moreover, further deepening of capital markets - driven in part by global investors' search for yield - also contributed by facilitating the issuance of local currencydenominated corporate bonds. Leverage ratios, measured as debt-to-assets, also increased markedly during the same period, notably in India, the Philippines, and Thailand, where they rose to around 35 percent or higher. While leverage rose, the share of short-term debt declined

\footnotetext{
${ }^{26}$ This discussion is based on a sample of listed and non-listed companies with market capitalization of more than US\$1 million, obtained from the S\&P Global Market Intelligence database. The sample includes firms (number provided in brackets for QIV 2019) from Australia (1653), Hong Kong SAR (1555), Japan (3861), Korea (2236), Singapore (574), China (4865), Indonesia (649), India (2855), Malaysia (954), Philippines (243), Thailand (769), and Vietnam (658). The sample size varies across variables and time for a given country or jurisdiction.

27 This is most evident in Australia, where the share of firms with negative profit accounts for 66 percent of total in 2019, while their assets amount to only $3 \frac{1}{2}$ percent of total.
} 
since 2007, especially among firms with higher leverage, which has helped reduce corporate vulnerability to liquidity shocks.

Chart A.2. Corporate Debt and Leverage: Nonfinancial Corporate (NFC) Sector
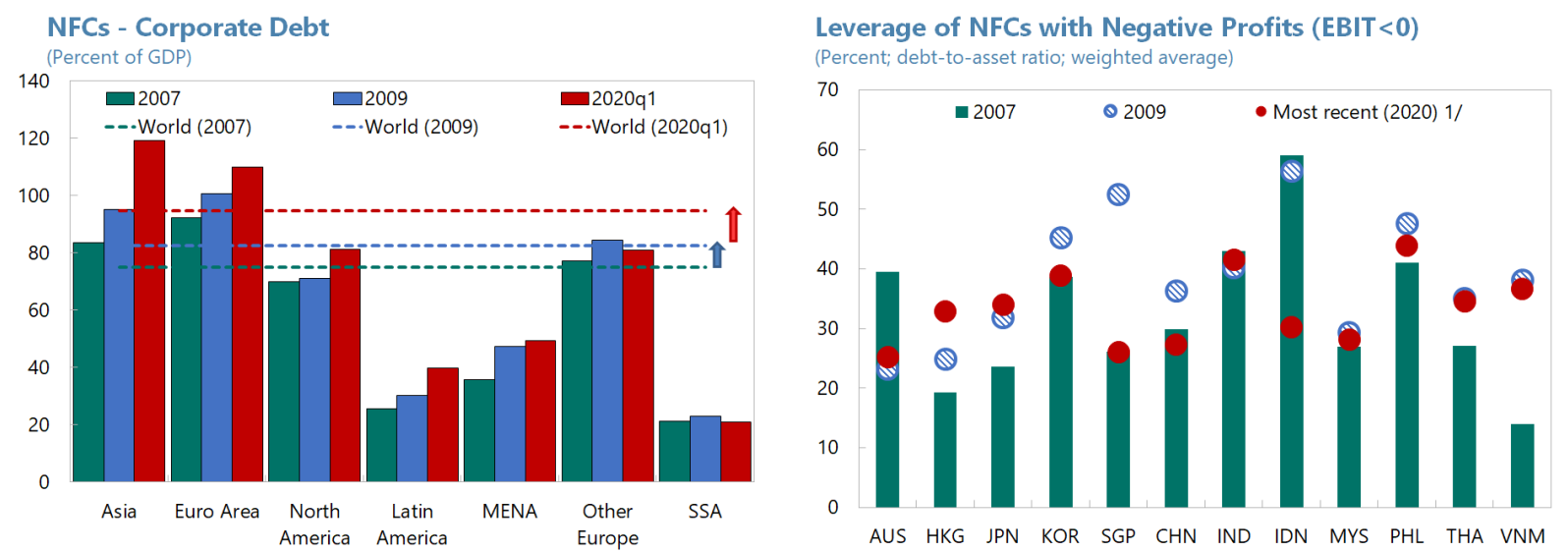

1/ The most recent data shows 2020q1 for Korea, China, India, Malaysia, Philippines, Thailand, and 2020q2 for Japan, Indonesia, and Vietnam. For Australia, Hong Kong SAR, Singapore, the data is based on 2019. Firms with market capitalization of at least US\$1 million are included. The weighted average is based on total assets. In the case of Australia, the most recent leverage data may be biased upward compared to earlier data due to a change in accounting standards (AASB16).

Sources: ADB, Asian Bonds Online; BIS; CEIC Data; Haver Analytics; S\&P Global Market Intelligence; and IMF staff calculations.

Falling profitability and rising debt burdens have increased the risk of financial distress among NFCs. This is reflected in the interest coverage ratio (ICR), which relates operational profits (earnings before interest and taxes) to interest expenses and, thus, provides an indicator of a firm's ability to service its debt using internal cash flows. Firms with an ICR of less than two are generally regarded as facing heightened risk to debt distress. This risk has risen, as the share of debt issued by firms with ICRs of less than 2 is higher now than during the GFC across the region (Chart A.3). ${ }^{28}$ The share of debt held by firms with an ICR below 2 has increased further since the outbreak of the pandemic.

\section{Chart A.3. Debt at Risk in Asia and the Pacific 1/}

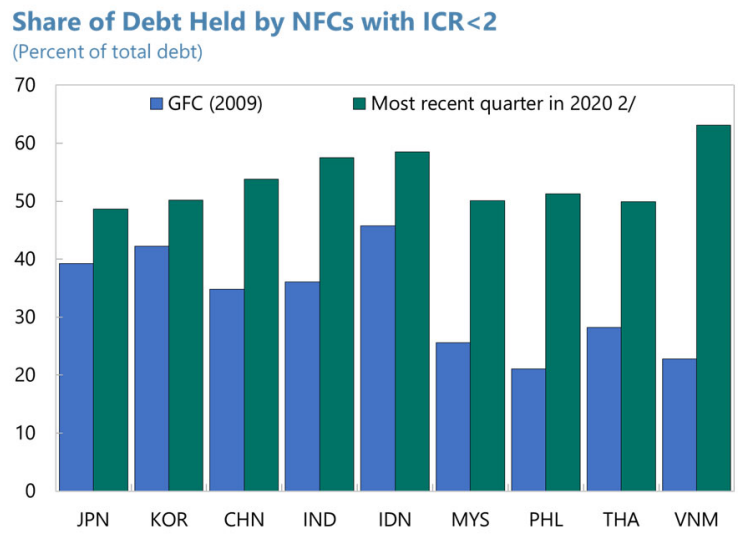

$1 /$ NFCs with capitalization of US\$1 million or more are included in the sample.

2/ The most recent data uses 2020Q2 for Japan, Indonesia, and Vietnam, and 2020Q1 for other countries.

Sources: S\&P Global Market Intelligence; and IMF staff calculations.

\footnotetext{
${ }^{28}$ The metrics in Singapore are driven by a couple of large firms.
} 


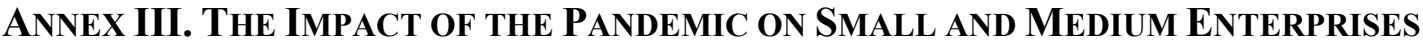

SMEs are important providers of jobs and contribute to inclusive growth in Asia and the Pacific. SMEs in the region account for 30-60 percent of the level of GDP and 30-90 percent of employment in their respective economies. ${ }^{29}$ SMEs also play an important role in providing opportunities for inclusive growth, as evidenced by a rising share of female owners over the past decade. While SMEs operate in a wide range of sectors, they are particularly concentrated in services, which makes them particularly vulnerable in this pandemic.

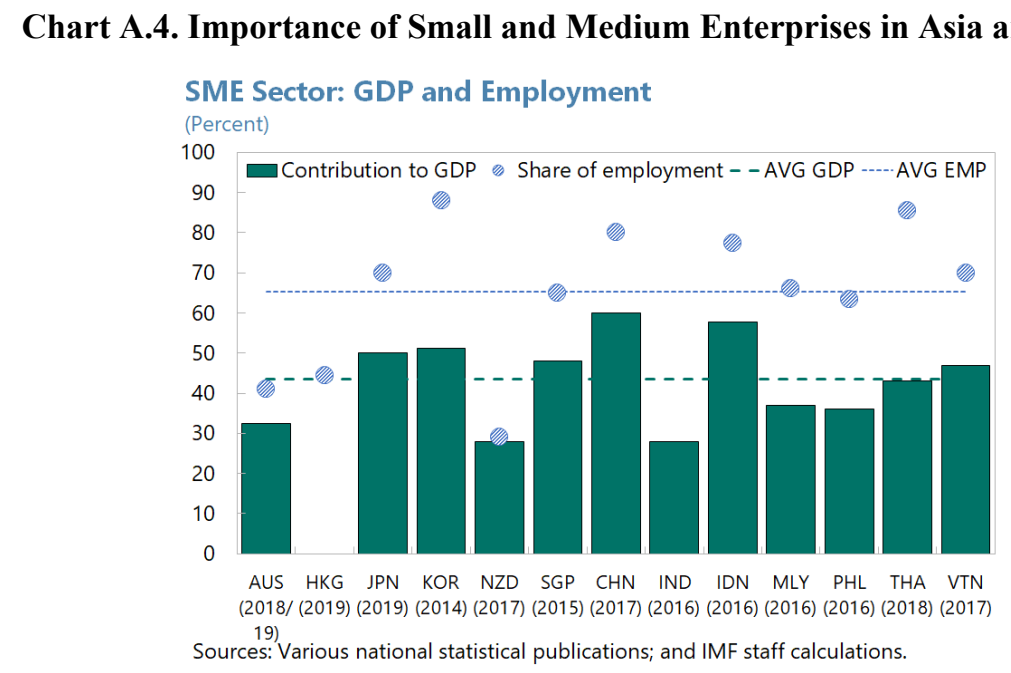

While systematic data on SME performance since the pandemic outbreak is scarce, surveys point to a severely negative impact to date:

- A global survey carried out in 50 countries in late May found that a quarter of the surveyed SME owners had closed their businesses between January and May 2020. ${ }^{30}$ The hospitality sector was hit the hardest, with around 50 percent shutting down. This said, nearly threequarters of the businesses that had closed expected to reopen once containment measures were lifted. Among the SMEs that remained in operation, about one-third reported a reduction in their workforce. The pandemic lockdown also disproportionately impacted female business owners as their commitments to provide home care rose disproportionally.

- Data compiled by the Ministry of SMEs and Startups in Korea showed that at the peak of the pandemic containment effort in early April, sales of small firms and merchants dropped by as much as 70 percent over a year ago, and by July sales were still down 30 percent. In a survey conducted in April by the Korean Federation of Micro Enterprises, almost half of the respondents indicated that they would consider closing their businesses if the COVID outbreak persisted for more than six months.

\footnotetext{
${ }^{29}$ The wide range of these estimates partly reflects differences in the definition of SMEs across countries.

30 "The Future of Business Survey", conducted in collaboration between Facebook, the Organization for Economic Co-operation and Development (OECD), and the World Bank. The survey includes responses by more than 30,000 owners, managers, and employees of small and medium-sized businesses across 50 countries in the world.
} 
- In Japan, the quarterly Tankan survey showed that business conditions severely deteriorated in the June quarter of 2020, compared to the March quarter. The deterioration was more pronounced among SMEs, particularly in the non-manufacturing industry.

- In Thailand, surveys showed a sharp drop in the willingness of households to invest in SMEs. 


\section{AnNeX IV. The COVID ShOCK AND STRUCTURAL CHANGE}

Structural change involves reallocation of resources (i.e., labor, capital, land, technology) within and across sectors in an economy. Resource reallocations are triggered by shocks to their relative returns. The literature (see Brainard and Cutler, 1990) distinguishes between two types of shocks. Aggregate shocks, commonly associated with the business cycle, cause transitory changes in the return of resources across firms and sectors, and thus have limited long-run effects. In contrast, reallocation shocks, cause permanent changes in relative returns and thus lead to permanent shifts of resources within and sectors. Reallocation shocks are commonly associated with changes in tastes and technology.

Economic crises are often accompanied by substantial resource reallocation and it is quite plausible that this will also be the case in the current crisis. A substantial part of the COVID-19 shock is likely to be cyclical and will reverse once containment measures are withdrawn and health risks recede. However, some behavioral responses of consumers and firms are accelerating technological disruptions and structural transitions already in train, such as the switch from brick-and-mortar to online retail or the increasing use of digital payments and finance. These changes are likely to persist even after the pandemic is brought under control. On the consumer side this could mean more shopping from home and less consumption of contact intensive services. On the corporate side, firms will likely adjust their operating models, with more decentralized use of their workforces (including through more work from home) and reconfigurations of supply chains to reduce the risks of disruptions in case of future pandemics and other shocks.

The permanent changes in consumer preferences and corporate operating technology will have implications for the viability of firms. They will require firms in some sectors to shrink, restructure, or exit. At the same time, they will also provide new growth opportunities in other sectors.

Measuring the extent of structural change and resource reallocation in real time is challenging. However, several indicators suggest that the COVID-19 shock involves a substantial element of reallocation. For the United States, Barrero et al. (2020) construct a forward-looking reallocation measure for jobs drawing on firm-level expectations at a one-year forecast horizon in the Survey of Business Uncertainty (SBU) and find a substantial increase after February 2020. Reallocation shocks are also expected to result in increases in the dispersion of equity returns, since the returns reflect the present discounted value of capital returns in the future (Brainard and Cutler, 1990). Sharp increases in the dispersion of equity returns following the COVID-19 shock have been observed in the United States (Barrero et al. 2020) and across many markets in Asia and the Pacific (Chart A.5.). Finally, the marked concentration of negative corporate credit rating actions in some sectors provides another piece of evidence to suggest that the current crisis can be expected to trigger significant resource reallocation. 


\section{Chart A.5. Equity Return Dispersion in Asia and the Pacific}

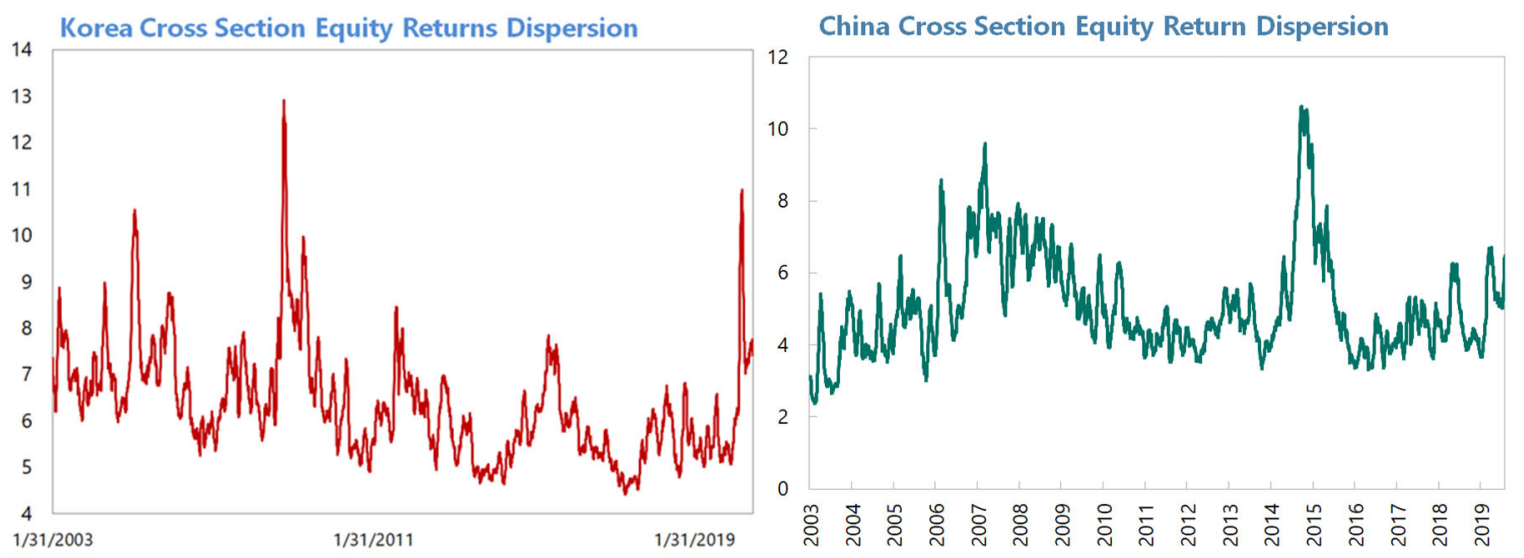

Thailand Cross Section Equity Return
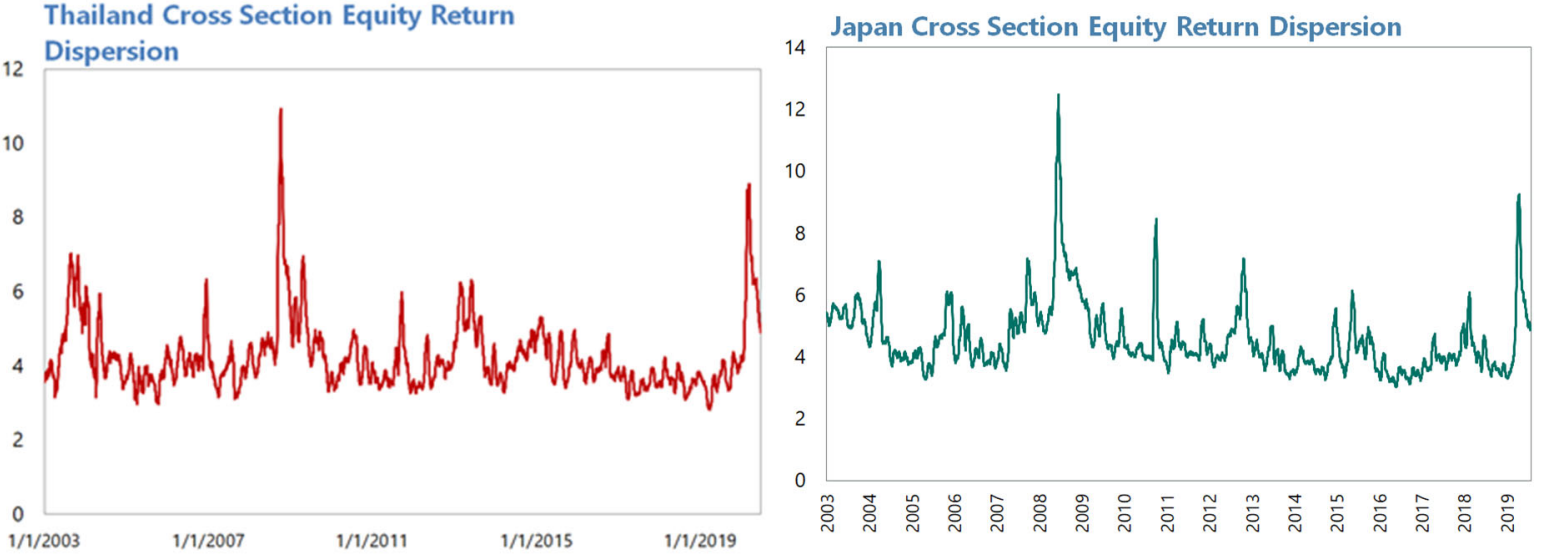

Sources: Bloomberg; and IMF staff calculations

Chart A.6. Sectoral Dispersion of Corporate Ratings Downgrades in 2020

Recently Downgraded NFCs with Speculative Ratings (Percent)

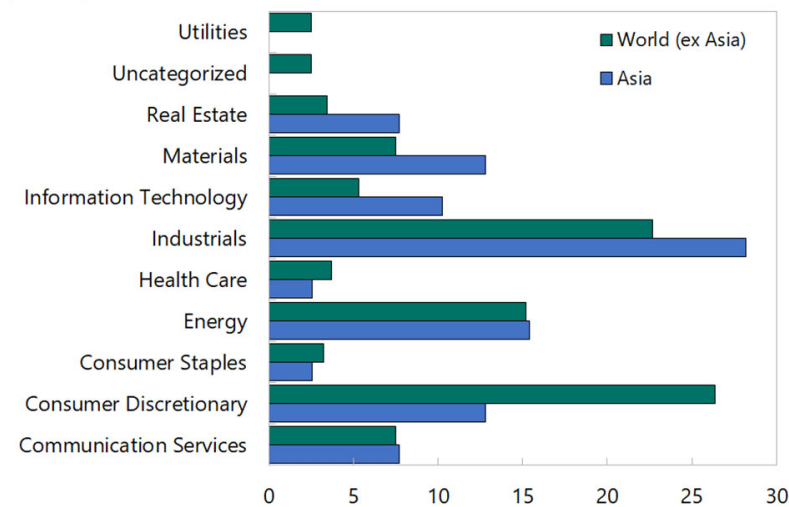

Note: Data for January-July, 2020.

Sources: S\&P Global Market Intelligence; and IMF staff calculations. 


\section{REFERENCES}

Altman, Edward, 2020, “Bankruptcy Guru Predicts Second Wave of Corporate Defaults," Dow Jones Wire (DJ), December 10.

Awad, Rachid, Caio Ferreira, Aldona Jociene, and Luc Riedweg, 2020, “Restriction of Banks' Capital Distribution during the COVID-19 Pandemic (Dividends, Share Buybacks, and Bonuses)", Special Series on COVID-19, International Monetary Fund https://www.imf.org/ /media/Files/Publications/covid19-special-notes/en-special-series-oncovid-19-restriction-of-banks-capital-distribution-during-the-covid-19-pandemic.ashx?la=en

Awad, Rachid, Caio Ferreira, Ellen Gaston, and Luc Riedweg, 2020b, "Banking Sector Regulatory and Supervisory Response to Deal with Coronavirus Impact (with Q and A)", Special Series on COVID-19, International Monetary Fund https://www.imf.org/ /media/Files/Publications/covid19-special-notes/enspecial-series-oncovid19banking-sector-regulatory-and-supervisory-response-to-deal-withcoronavir.ashx?la=en

Banerjee, Ryan, Giulio Cornelli and Egon Zakrajšek, 2020, “The Outlook for business Bankruptcies," Bank for International Settlement Bulletin No. 30.

Barrero, Jose Maria, Nicholas Bloom, and Steven J. Davis, 2020, “COVID-19 Is Also a Reallocation Shock', NBER Working Paper No. 27137 https://www.nber.org/papers/w27137

Bergthaler, Wolfgang, Kenneth Kang, Yan Liu, and Dermot Monaghan, 2015, “Tackling Small and Medium Sized Enterprise Problem Loans in Europe," IMF SDN 15/04, https://www.imf.org/external/pubs/ft/sdn/2015/sdn1504.pdf

Bernstein, S., Colonelli, E., and B. Iverson, 2019a, “Asset Allocation in Bankruptcy”, The Journal of Finance, 74, No 1, 5-53.

Bernstein, S., Colonelli, E., Giroud, X., and B. Iverson, 2019b, "Bankruptcy Spillovers", Journal of Financial Economics, 133, No. 3, 608-633.

Blank, Michael, Samuel G. Hanson, Jeremy C. Stein, and Adi Sunderam, 2020, "How Should U.S. Bank Regulators Respond to the COVID-19 Crisis?", Hutchins Center Working Paper \#63.

Brainard, S. Lael and David M. Cutler, 1990, "Sectoral Shifts and Cyclical Unemployment Reconsidered”, NBER Working Paper No 3491 https://www.nber.org/papers/w3491

Calomiris, Charles W., 2013, "Reforming Banks Without Destroying Their Productivity and Value", Journal of Applied Corporate Finance, Volume 25, Number 4.

Carletti, Elena, Stijn Claessens, Antonio Fatás, and Xavier Vives, 2020, The Bank Business Model in the post-Covid-19 World. Vox EU Blog https://voxeu.org/article/bank-businessmodel-post-covid-19-world 
Celerier, Claire, Thomas K. Kick, and Steven R. G. Ongena, 2019, Taxing Bank Leverage: The Effects on Bank Portfolio Allocation (May 15, 2019). Available at SSRN: https://ssrn.com/abstract=2829326 or http://dx.doi.org/10.2139/ssrn.2829326

Claessens, S., 2005, "Policy Approaches to Corporate Restructuring around the World: What Worked, What Failed?", in M. Pomerleano and W. Shaw (eds.), Corporate Restructuring. Lessons from Experience, World Bank, Washington D.C., 11.

Cohen, Benjamin H. and Michela Scatigna, 2016, "Banks and Capital Requirements: Channels of Adjustment", Journal of Banking and Finance 69, S56-69.

De Mooij, Ruud, Michael Keen, and Alexander Tieman, 2016, "Fixing the Great Distortion: How to Undo the Tax Bias Toward Debt Finance", IMF Blog https://blogs.imf.org/2016/11/10/fixing-the-great-distortion-how-to-undo-the-tax-biastoward-debt-finance/

Dobler, Marc C., Alvaro Piris Chavarri, and Marina Moretti, 2020, "Managing Systemic Banking Crises: New Lessons and Lessons Relearned”, IMF Departmental Paper No. 20/05.

Garrido, Jose M., 2012, Out-of-Court Debt Restructuring, World Bank Study, World Bank.

Garrido, Jose, Sanaa Nadeem, Nagwa Riad, Chanda DeLong, Nadia Rendak, and Anjum Rosha, 2020, "Tackling Private Over-Indebtedness in Asia: Economic and Legal Aspects", IMF WP 20/172, https://www.imf.org/en/Publications/WP/Issues/2020/08/28/Tackling-PrivateOver-Indebtedness-in-Asia-Economic-and-Legal-Aspects-49704

Garrido, Jose M. (dir.), Wolfgang Bergthaler, Chanda DeLong, Juliet Johnson, Amira Rasekh, Anjum Rosha, and Natalia Stetsenko, 2019, "The Use of Data in Assessing and Designing Insolvency Systems", IMF WP 19/27, https://www.imf.org/en/Publications/WP/Issues/2019/02/04/The-Use-of-Data-in-Assessingand-Designing-Insolvency-Systems-46549

Grigorian, David, and Raei, Faezeh, 2010, Government Involvement in Corporate Debt Restructuring: case Studies from the Great Recession, IMF WP 10/60, https://www.imf.org/en/Publications/WP/Issues/2016/12/31/Government-Involvement-inCorporate-Debt-Restructuring-Case-Studies-from-the-Great-Recession-24365

International Monetary Fund, 2018, "Regional Economic Outlook-Asia and the Pacific", Asia and the Pacific Department. https://www.imf.org/en/Publications/REO/APAC/Issues/2018/10/05/areo1012 , 2020, “Main Operational Aspects for Macroprudential Policy Relaxation”, Special Series on COVID-19, Monetary and Capital Markets Department. , 2020b, "World Economic Outlook—October 2020”. 
and The World Bank, 2020, "COVID-19: The Regulatory and Supervisory Implications for the Banking Sector,” Joint Staff Position Note.

Iverson, Benjamin, 2018, "Get in Line: Chapter 11 Restructuring in Crowded Bankruptcy Courts,“"Management Science 64(11): 5370-5394.

Jester, Dan, David Nason, and Jeremiah Norton, 2018, "Recapitalizing the Banking System", in Ben Bernanke, Timothy F Geithner and Henry M. Paulson Jr Eds., "First RespondersInside the U.S. Strategy for Fighting the 2007-2009 Global Financial Crisis," Yale University Press, New Haven and London.

Kang, Kenneth and Chang Yong Rhee, 2020, A Post-Coronavirus Recovery in Asia-Extending a "Whatever it Takes" Lifeline to Small Businesses, IMF Blog, April 23, https://blogs.imf.org/2020/04/23/a-post-coronavirus-recovery-in-asia-extending-a-whateverit-takes-lifeline-to-small-businesses/

Laryea, Thomas, 2010, Approaches to Corporate Debt Restructuring in the Wake of Financial Crises, IMF SPN 10/02, https://www.imf.org/external/pubs/ft/spn/2010/spn1002.pdf

Li, Lei, 2013, “TARP Funds Distribution and Bank Loan Supply”, Journal of Banking \& Finance 37, 4777-4792.

Liu, Yan, Garrido, Jose, and DeLong, Chanda, 2020, Private Debt Resolution in the Wake of the Pandemic, Special Series on COVID-19, International Monetary Fund. https://www.imf.org/ /media/Files/Publications/covid19-special-notes/en-special-series-oncovid-19-private-debt-resolution-measures-in-the-wake-of-the-pandemic.ashx

Majluf, Nicholas S. and Stewart C. Myers, "Corporate Financing and Investment Decisions when Firms Have Information that Investors Do Not Have", Journal of Financial Economics 13 (1984) 187-221.

Mako, William P., 2001, "Corporate Restructuring in East Asia: Promoting Best Practices", Finance and Development, Vol. 38, No. 1.

Tomasic, Roman and Little, Peter, 1998, "Corporate Insolvency and Self-help in Six Asian Legal Systems," 6 Insolvency Law Journal, 63. 